\title{
Poverty, Undernutrition and Vulnerability in Rural India: Public Works versus Food Subsidy ${ }^{1}$
}

\author{
Raghbendra Jha \\ Australia South Asia Research Centre, Australian National University, Australia
}

Katsushi S. Imai*

Economics, School of Social Sciences, University of Manchester, UK, \&

\section{Raghav Gaiha}

Centre for Population Development Studies, Harvard University, US

and Faculty of Management Studies, University of Delhi, India

$25^{\text {th }}$ November 2008

\begin{abstract}
This paper analyses the effects of access to Rural Public Works (RPW) and Public Distribution System (PDS), a public food subsidy programme, on consumption poverty, vulnerability and undernutrition in India drawing upon the large household data sets constructed by National Sample Survey (NSS) data, 50th round in 1993-1994 and 61st round in 2004-2005. Treatment-effects model and Propensity Score Matching (PSM) model are used to take account of the sample selection bias in evaluating the effects of RPW or PDS on poverty. We have found significant and negative effects of the household participation in RPW and Food for Work Programmes on poverty, undernutrition (e.g. protein) and vulnerability in 1993 and 2004. On the contrary, poverty and undernutrition are significantly higher for the households with access to PDS than those without, whilst PDS has significant effects on reducing vulnerability of households in 1993 and 2004. We also applied the pseudo panel model which confirms that PDS decreased the vulnerability based on $80 \%$ of the poverty threshold. However, state-wise results of treatment effects model show considerable diversity of policy effects among different states.
\end{abstract}

Key Words: Poverty, Undernutrition, Vulnerability, Rural Public Works (RPW), Public Distribution System (PDS), Poverty Reduction Policy, Treatment Effects Model, Propensity Score Matching (PSM) Model, India

JEL Codes: C21, C23, C31, I32, I38, O15, O22

*Corresponding Author:

Katsushi Imai (Dr)

Economics, School of Social Sciences, Arthur Lewis Building

University of Manchester, Oxford Road, Manchester M13 9PL, UK

Phone: +44-(0)161-275-4827; Fax: +44-(0)161-275-4928

E-mail: Katsushi.Imai@manchester.ac.uk

\footnotetext{
1 This study is funded by the Australian Research Council-AusAID Linkage grant LP0775444. The second author acknowledges the small grant from DFID and Chronic Poverty Research Centre in the UK under the DFID project on social protection and poverty led by Armando Barrientos, at Brooks World Poverty Institute (BWPI) of University of Manchester. We have benefited the advice from Armando Barrientos and Takahiro Sato. We are grateful for research assistance and advice from Tu Dang. The views expressed are, however, those of the authors' and do not necessarily represent those of the organisations to which they are affiliated.
} 


\section{Poverty, Undernutrition and Vulnerability in Rural India Public Works versus Food Subsidy}

\section{Introduction}

Despite the recent economic growth at national level in India, concerns have been raised over the disparity of the poverty levels as well as the speed of the poverty reduction in recent years (e.g. Jha and Gaiha, 2003, Kijima 2006, Himanshu 2007). Disparity could arise from geographical locations (e.g. among different states or between urban and rural areas) or among social groups or castes (Kijima, 2006, Gaiha et al., 2007, King et al. 2006). However, there has been no consensus as to what is the best option for a set of policy options to reduce poverty efficiently at national scale. While policies to promote the macro economic growth is necessarily to reduce poverty, targeted interventions directly to support the poor have been in operation and considered as the crucial component in public policies in India at both government and state levels because the economic growth per se would not be sufficient to reduce poverty of those in backward areas or in disadvantaged social groups who lack easy access to the market or education.

Due to the advantages arising from their salient features, such as self-targeting, ${ }^{2}$ the Rural Public Works (RPWs) have been considered one of the best alternatives. However, the previous assessment of RPWs pointed out that they are fid not reach the poor effectively (e.g. Gaiha et al., 2001). The past literature also suggested that the workers who are poor do not have enough incentives to participate in the scheme through the poverty trap where those under the threshold will be either left out of the labour market (or unemployed) (e.g. Dasgupta, 1997) or receive the only marginal wages as they cannot carry out physically demanding tasks due to the undernutrition or poor health. This would imply the difficulty evaluating RPWs on poverty as poverty or undernutrition not necessarily is not necessarily their outcomes, but also affects the participation decision. The rigorous empirical work to examine the relationship between RPWs and poverty is of enormous help in driving policy implications. The purpose of this paper is to statistically assess whether the participation in RPWs affect poverty defined in consumption expenditure based on the National Sample

\footnotetext{
2 In self targeting,the participants themselves decide to participate in the scheme explicitly or implicitly by comparing the potential benefits (e.g. wage incomes, reduction of seasonality or risk) and costs (e.g. physical labour, transportation costs, opportunity costs). Better targeting performance through work requirements would lead to the better cost effectiveness of poverty interventions as put forward as 'screening arguments' by Besley and Coates (1992).
} 
Survey data in the $50^{\text {th }}$ round in 1993-1994 and the $61^{\text {st }}$ in 2004-2005, two rounds of the large national-scale household data. We use the data of participations in RPWs for the $50^{\text {th }}$ round and those on FFW (Food for Work) programme, a version of RPWs, for the $61^{\text {st }}$ round because of the data constraints. ${ }^{3}$

As a comparison to RPWs, the present study will evaluate the poverty reducing effects of Public Distribution System (PDS), the public scheme of food subsidy under which poor people provided with basic food at subsidized price (e.g. rice, wheat,

sugar, edible oil, soft cake and kerosene oil). While RPW has an advantage over PDS due to the nature of self-selection, PDS could be accessed by those who are unable to work (e.g. the elderly or the physically disabled). PDS is likely to have an impact on nutritional conditions of household members because of its provision of food. However, there are relatively few systematic and rigorous studies to evaluate the impact of PDS on poverty. ${ }^{4} 5$

However, it is not straightforward to evaluate the effects of RPW or PDS on poverty because of the endogeneity or the sample selection problem associated with access to these schemes. The participation in RPW is likely to be endogenous either because of the endogenous programme placement where policy makers purposefully allocate the fund according to the objectives of the programme (e.g. poverty alleviation in the remote area or disadvantage groups) or the self-selection. The geographical placement of PDS may not be random, or could be endogenous.

This paper will take into account the endogeneity in assessing RPWs in two ways. First, we will employ treatment effects model, a version of Heckman sample Selection Model (Heckman, 1979) where the participation equation is estimated and in the second stage poverty or consumption is estimated by the predicted participation among other determinants. Second, the propensity score matching (PSM) model would be applied to statistically

\footnotetext{
3 The data on RPWs in the $50^{\text {th }}$ round and those on FFW in the $61^{\text {st }}$ round are the most reliable with relatively few missing observations,

4 An important exception is Bhalotra (2002) who analysed the effects of PDS on child nutrition. She found based on the household data collected by the National Council of Applied Economic Research (NCAER) in 1994 that (i) if the average subsidy for the average household on PDS is 23 per cent, then the PDS-using household buys 23 per cent more food and (ii) the additional expenditure on food translatesinto statistically significant increases of 0.09 standard deviations in height and 0.05 standard deviations in weight for boys, and into smaller increases for girls.

5 See Bhalotra (2002, Table 2) for the importance of PDS and RPW in central plan budgetary expenditure in India where PDS had a share of 3.2\% and rural employment programmes had $2.3 \%$ in 1997, the highest shares among other alternatives. This suggests that these are the two major programmes to support the rural poor in India.
} 
compare the poverty measures for those who have access to RPWs and for those who do not and are matched by the propensity score derived by the probit or logit model where the characteristics of the households are taken into account.

The PSM first estimates probit or logit model to estimate a function matching the proximity of one household to another in terms of household characteristics and then households are grouped to minimize the distance between matched cases. While it has some advantages over the IV (instrumental variable) model (e.g. not requiring the instrument or linearity as in the IV model), the sample selection bias would not be entirely corrected if there are important unobservable variables which would affect the household decision to participate in the programmes (e.g. health, intra-household bargaining, cultural or psychological factors which are not found in the data). Treatment effects model also estimates the probit model with the similar specification as in the first stage of PSM. In the second stage, the poverty measure is estimated by OLS while sample selection is corrected by using the estimates of probability of participating in the microfinance programmes. The model is fitted by a full maximum likelihood (Maddala, 1983). The merits of treatment effects model over PSM include that (i) the degree of sample selection is explicitly taken into account in the model and (ii) the determinants of the dependent variable in the second stage are identified. However, the treatment effects model imposes the strong distributional assumptions for the functions in both stages and the final results are highly sensitive to the choice of explanatory variables and the instrument. The presence of unobservable variables would also affect the results as in PSM. Given these limitations, applying different models would be useful as one model would serve to check the robustness of the results derived by another model.

The present study goes beyond the standard definition of poverty which concerns the binary measure defined by the national poverty line based on income or consumption data. First, for $50^{\text {th }}$ round, we use the data on undrnutrition in terms of calories and proteins, which has been constructed by converting the detailed food expenditure data available in NSS 50-1.0 into their nutritional equivalents (Jha and Gaiha, 2003). That is, whether a household is poor defined not only by the consumption but also by nutritional deficiencies. This is important in light of the link of the labour market participation and nutrition, which leads to the nutrition-based poverty trap. Second, we have derived the vulnerability measures as the probability of a household falling into poverty using the cross-sectional estimation drawing 
upon Chaudhuri (2003) and Chaudhuri et al. (2003). While poverty and vulnerability are correlated, they are different as some households above the poverty threshold may be vulnerable, or those who are just below the poverty line but have secure income sources may not be vulnerable (e.g. Gaiha and Imai, 2009). Hence, the effects of RPW or PDS on poverty and those on vulnerability are likely to be different- given the high vulnerability in the backward areas, the policy role of reducing vulnerability or protecting households vulnerable shocks is very important.

The rest of the paper is organised as follows. Section II briefly explains the data. Section III describes the econometric methodologies which we have used to estimate the treatment-effects and PSM models. Section IV provides the econometric results and main findings. The concluding remarks are given in the final section.

\section{Data}

\section{(1) NSS data}

The NSS, set up by the Government of India in 1950, is a multi-subject integrated sample survey conducted all over the India level in the form of successive rounds relating to various aspects of social, economic, demographic, industrial and agricultural statistics. ${ }^{6}$ We mainly use the data in the 'Household Consumer Expenditure' schedule, called 'the scheduled 01', quinquennial surveys in the $50^{\text {th }}$ round, 1993-4 and in the $61^{\text {st }}$ round, 2004-5. ${ }^{7}$ These form the repeated cross-section data sets, each of which contains a large number of households across India. ${ }^{8}$ The consumption schedule contains a variety of information related to mean per capita expenditure (MPCE), disaggregated expenditure over many items together with basic socio economic characteristics of the household (e.g. sex, age, religion, caste, and land-holding). To derive wages at the level of NSS region, we supplement the consumption schedule by 'Employment and Unemployment' schedule called 'the scheduled 10' which has the data of employment and unemployment situations.

\footnotetext{
${ }^{6}$ See the website of National Sample Survey Organisation http://mospi.nic.in/nsso test1.htm for more details of NSS.

${ }^{7}$ We are not using $55^{\text {th }}$ round in $1999-2000$ as the consumption data in $55^{\text {th }}$ round are not comparable with those in $50^{\text {th }}$ or $61^{\text {st }}$ round because of the change in the recalling periods. The consumption data are comparable between $50^{\text {th }}$ round and $61^{\text {st }}$ round.

8 After dropping the households with missing observations in one of the explanatory variables, the number of households used for the estimation is 69206 and 78999 respectively for $50^{\text {th }}$ and $61^{\text {st }}$ round.
} 
NSS covers the whole of the Indian Union except (i) Leh (Ladakh) and kargil districts of Jammu \& Kashimir, (ii) interior villages of Nagaland situated beyond the kilometers of the bus route and (iii) villages in Andaman and Nicobar Islands which remain inaccessible throughout the year. In this study, we will use the data in 'Household Consumer Expenditure' schedule in $50^{\text {th }}$ round and $61^{\text {st }}$ round because the data on Rural Pubic Works in the 'Employment and Unemployment' have a lot of missing observations. Definitions and Descriptive Statistics of the variables are shown in Appendix 1. The latter is presented for those with or without access to RPW (or PDS).

While the data on which household participated in RPWs were collected by the consumption schedule of NSS $50^{\text {th }}$ round, only the data on the participation FFW or Food for Works are available in $61^{\text {st }}$ round. Hence these participation data are not strictly comparable, but we use these data as proxies for the household-level access to RPW, that is, whether any member of the household participated in RPW. The access to PDS is defined as whether a household obtained any food items by PDS. One limitation in our approach is that we do not take account of how many days the household member participated in the RPW or how much a household obtained food by PDS assuming that a household as a unit through collective decision-making by household members, makes a decision on whether it should participate in RPW or us PDS given the household conditions. This assumption, which may not reflect the reality, is required as the data on RPW or FFW and PDS are available only at household levels.

\section{(2) Computation of Nutritional Deficiency ${ }^{9}$}

For NSS $50^{\text {th }}$ round, we have derived the nutrition-based poverty cut-off points by taking into account calorie and protein intakes as well as minimum cut-off points for either on the assumption of moderate work (Gopalan, 1992, Gopalan et. al., 1971). The official poverty line takes into account the cost of a nutritionally adequate diet in terms of per capita consumption expenditure. The poverty line is taken as per capita consumption worth Rs. 49 (Rs. 57) at 1973-74 prices for the rural (urban) sector. Expenditure is used as a proxy for income, since the NSS does not collect income data. Estimates using these poverty lines have been made by a number of authors. We derived nutritional deficiency calculated using nutritional equivalents of actual consumption baskets for households compared against recommended daily allowance

\footnotetext{
${ }^{9}$ See Jha and Gaiha (2003) for more details. The computation of nutritional deficiency for NSS $61^{\text {st }}$ round would be an important extension for the future study.
} 
as elaborated in Gopalan et al. (1971). The daily nutritional requirements as reported by Gopalan et al. are reproduced in Appendix 2. We use energy per capita and protein per capita from the NSS $50^{\text {th }}$ round data files converted into nutritional equivalents. These data are computed as total consumption (of calories, protein and other nutrients) of the households divided by variable "members" where the number of members in a household is calculated by giving unit weights to the adults and 0.5 weight to the children. Age specific weights for children are not possible since ages of children are not recorded.

\section{Econometric Models}

\section{(1) Deriving Vulnerability Measures using Large Cross-sectional data}

It would be ideal to use panel data to derive household's vulnerability measures, but we could derive the measure of 'Vulnerability as Expected Poverty' (VEP), an ex ante measure based on Chaudhuri (2003) and Chaudhuri, Jalan and Suryahadi (2002), who applied it to a large cross-section of households in Indonesia ${ }^{10}$ and defined vulnerability as the probability that a household will fall into poverty in the future.

$$
\mathrm{VEP}_{\text {it }} \equiv \mathrm{V}_{\mathrm{it}}=\operatorname{Pr}\left(\mathrm{c}_{\mathrm{i}, \mathrm{t}+1} \leq \mathrm{z}\right)
$$

where vulnerability of household $i$ at time $t, V_{i t}$, is the probability that the $i$-th household's level of consumption at time $\mathrm{t}+1, \mathrm{c}_{\mathrm{i}, \mathrm{t}+1}$, will be below the poverty line, $\mathrm{z}$.

Three limitations, amongst others, should be noted in our measure of vulnerability. First, the present analysis is confined to a consumption (used synonymously with income) threshold of poverty. Second, our measure of vulnerability in terms of the probability of a household's consumption falling below the poverty threshold in the future is subject to the choice of a threshold. ${ }^{11}$ Third, while income/consumption volatility underlies vulnerability, the resilience in mitigating welfare losses depends on assets defined broadly-including human, physical and social capital. A household with inadequate physical or financial asset or savings, for example, may find it hard to overcome loss of income. This may translate into lower nutritional intake and rationing out of its members from the labour market (Dasgupta,

10 See a summary by Hoddinott and Quisumbing (2003a, b) of methodological issues in measuring vulnerability.

11 One of the limitations of this definition of vulnerability is that it is sensitive to the choice of $z$. We have defined the poverty line based on the national poverty line and checked the sensitivity of the results by applying different levels of poverty line (i.e. $120 \%$ and $80 \%$ ). 
1997; Foster, 1995). Lack of physical assets may also impede accumulation of profitable portfolios under risk and generate poverty traps (Fred and Carter, 2003).

The consumption function is estimated by the equation (2). ${ }^{12}$

$$
\ln \mathrm{c}_{\mathrm{i}}=\mathrm{X}_{\mathrm{i}} \beta+\mathrm{e}_{\mathrm{i}}
$$

where $c_{i}$ is mean per capita consumption (MPCE) (i.e. food and non-food consumption expenditure) for the $i-$ th household and $\mathrm{X}_{\mathrm{i}}$ is a vector of observable household characteristics and other determinants of consumption. ${ }^{13}$ These include;

$A_{i}$ : A set of variables on household composition, such as whether a household is headed by a female member, number of adult male or female members, share of adult members in the household)

$E_{i}$ : A set of the variables on the highest level of educational attainment of household members (e.g. whether completed primary school, secondary school, or higher education).

$L_{i}$ : Owned land as a measure of household wealth.

$\Omega_{i}$ : Occupation of parents in terms of (i) whether the household is classified as non-agricultural self-employment and (ii) whether as agricultural self-employment.

$E_{i}$ : Social backwardness of the household in terms of (i) whether a household belongs to scheduled caste and (ii) whether it belongs to scheduled tribe.

$D$ : A vector of state dummy variables.

$\beta$ is a vector of coefficients of household characteristics, and $e_{i}$ is a mean-zero disturbance term that captures idiosyncratic shocks to per capita consumption. It is assumed that the structure of the economy is relatively stable over time and, hence, future consumption stems solely from the uncertainty about the idiosyncratic shocks, $e_{i}$. It is also assumed that the variance of the disturbance term depends on:

$$
\sigma_{\mathrm{e}, \mathrm{i}}^{2}=\mathrm{X}_{\mathrm{i}} \theta
$$

\footnotetext{
${ }^{12}$ We have used White-Huber sandwich estimator to overcome heteroscedasticity in the sample.

13 See Appendix 1 for definitions of the variables. These variables are used to estimate poverty and undernutrition equations.
} 
The estimates of $\beta$ and $\theta$ are obtained using a three-step feasible generalized least squares (FGLS). ${ }^{14}$ Using the estimates $\hat{\beta}$ and $\hat{\theta}$, we can compute the expected log consumption and the variance of log consumption for each household as follows.

$$
\begin{aligned}
& E\left[\ln C_{i} \mid X_{i}\right]=X_{i} \hat{\beta} \\
& V\left[\ln C_{i} \mid X_{i}\right]=X_{i} \hat{\theta}
\end{aligned}
$$

By assuming $\ln c_{i}$ as normally distributed and letting $\Phi($.$) denote the cumulative$ density function of the standard normal distribution, the estimated probability that a household will be poor in the future (say, at time $\mathrm{t}+1$ ) is given by:

$$
\mathrm{VEP}_{\mathrm{i}} \equiv \hat{\mathrm{v}}_{\mathrm{i}}=\hat{\operatorname{Pr}}\left(\ln \mathrm{c}_{\mathrm{i}}<\ln \mathrm{z} \mid \mathrm{X}_{\mathrm{i}}\right)=\Phi\left(\frac{\ln \mathrm{z}-\mathrm{X}_{\mathrm{i}} \hat{\beta}}{\sqrt{\mathrm{X}_{\mathrm{i}} \hat{\theta}}}\right)
$$

This is an ex ante vulnerability measure that can be estimated with cross-sectional data. Note that this expression also yields the probability of a household at time $t$ becoming poor at $t+1$ given the distribution of consumption at $t$.

A merit of this vulnerability measure is that it can be estimated with cross-sectional data. However, it correctly reflects a household's vulnerability only if the distribution of consumption across households, given the household characteristics at time $t$, represents time-series variation of household consumption. Hence this measure requires a large sample in which some households experience a good time and others suffer from negative shocks. Also, the measure is unlikely to reflect unexpected large negative shocks (e.g. Asian financial crisis), if we use the cross-section data for a normal year.

\section{(2) Estimation of Wage Equations}

As the employment schedule of NSS provides us with individual data of earnings during the previous week of the survey date, these could be used as proxies for wages. We estimate the male and female wage equations by Tobit model.

$$
\begin{aligned}
& w_{j}^{M a l e}=w_{j}^{M a l e}\left(E_{j,} A_{j}, B_{i}, O_{t}, M_{t} E_{t} D\right)
\end{aligned}
$$

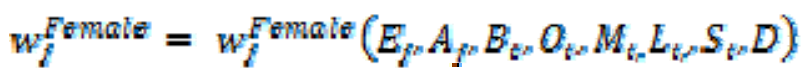

\footnotetext{
${ }^{14}$ See Chaudhuri (2003), Chaudhuri et al. (2002), and Hoddinott and Quisumbing (2003b) for technical details.
} 
Here wage for workers is estimated by a set of variables at individual levels for the individual $j$, such as a set of education dummies, $E_{j}$, age or its square, denoted as a vector, $A_{i}$. Other variables include $B_{i}$ : Social backwardness of the household; $O_{i}$ : Occupation; $M_{i}$ Religion of the household, $L_{i}$ : Owned land as defined before. This will give us predicted wages for male and female workers, $\omega_{j}^{N a l e}$ and $\omega_{j}^{F m a i s}$ which will be aggregated the level of NSS regions and used as one of the determinants of participation in RPWs.

Aggregation is necessary because the consumption schedule and the employment schedule survey different samples of households. These are used as instruments for the access to RPW. For the instrument of PDS, we use the food price index derived by the method of Deaton and Tarozzi (2000).

\section{(3) Treatment Effects Model}

We employ the treatment effects model, a version of the Heckman sample selection model (Heckman, 1979), which estimates the effect of an endogenous binary treatment. This would enable us to take account of the sample selection bias associated with the access to RPW or PDS. In the first stage, the access to RPW (or PDS) is estimated by the probit model. In the second, we estimate poverty (or a binary variable on whether the household is below the poverty threshold), underbutrition (or a binary variable on whether the household is below the threshold of calorie or protein intakes, only for NSS $50^{\text {th }}$, and the vulnerability measure after controlling for the inverse Mill's ratio which reflects the degree of sample selection bias. The instruments are the predicted individual wages aggregated at the level of NSS regions for RPW and the food price index for PDS. They are admittedly not ideal instruments in terms of the exclusion restrictions, but the data set does not contain any better variables for instruments, which are correlated with RPW or PDS, but not with poverty.

The merit of treatment effects model is that sample selection bias is explicitly estimated by using the results of probit model. Also, it would not require the two conditions for PSM which will be discussed in the next sub-section. However, the weak aspects include (i) the strong assumptions are imposed on distributions of the error terms in the first and the second stages, (ii) the results are sensitive to choice of the explanatory variables and instruments, and (iii) the valid instruments are rarely found in the non-experimental data.

The selection mechanism by the probit model above can be more explicitly specified as (e.g. Greene, 2003): 


$$
D_{i}^{*}=\gamma X_{i}+u_{i}
$$

and $D_{i}^{*}=1$ if $D_{i}^{*}=\gamma X_{i}+u_{i}>0$

$$
\mathrm{D}_{\mathrm{i}}^{*}=0 \text { otherwise }
$$

where $\operatorname{Pr}\left\{\mathrm{D}_{\mathrm{i}}=1 \mid \mathrm{X}_{\mathrm{i}}\right\}=\Phi\left(\gamma^{\prime} \mathrm{X}_{\mathrm{i}}\right)$

$$
\operatorname{Pr}\left\{\mathrm{D}_{\mathrm{i}}=0 \mid \mathrm{X}_{\mathrm{i}}\right\}=1-\Phi\left(\gamma^{\prime} \mathrm{X}_{\mathrm{i}}\right)
$$

$\mathrm{D}_{\mathrm{i}}^{*}$ is a latent variable. In our case, $\mathrm{D}_{\mathrm{i}}$ takes 1 if a household has access to RPW (or PDS) and 0 otherwise and $\mathrm{X}_{\mathrm{i}}$ is a vector of household characteristics and other determinants. $\Phi$ denotes the standard normal cumulative distribution function.

The linear outcome regression model in the second stage is specified below to examine the determinants of poverty, undernutrition or vulnerability denoted as $\mathrm{W}_{\mathrm{i}}$. That is,

$$
\begin{aligned}
& \mathrm{W}_{\mathrm{i}}=\beta^{\prime} \mathrm{Z}_{\mathrm{i}}+\theta \mathrm{D}_{\mathrm{i}}+\varepsilon_{\mathrm{i}} \\
& \left(\mathrm{u}_{\mathrm{i}} \varepsilon_{\mathrm{i}}\right) \sim \text { bivariate normal }\left[0,0,1, \sigma_{\varepsilon}, \rho\right] .
\end{aligned}
$$

where $\theta$ is the average net wealth benefit of accessing RPW or PDS.

Using a formula for the joint density of bivariate normally distributed variables, the expected poverty (or undernutrition or vulnerability) for those with access to RPW (or PDS) is written as:

$$
\begin{aligned}
E\left[W_{i} \mid D_{i}=1\right] & =\beta^{\prime} Z_{i}+\theta+E\left[\varepsilon_{i} \mid D_{i}=1\right] \\
& =\beta^{\prime} Z_{i}+\theta+\rho \sigma_{\varepsilon} \frac{\phi\left(\gamma^{\prime} X_{i}\right)}{\Phi\left(\gamma^{\prime} X_{i}\right)}
\end{aligned}
$$

where $\phi$ is the standard normal density function. The ratio of $\phi$ and $\Phi$ is called the inverse Mill's ratio.

Expected poverty (or undernutrition or vulnerability) for non-clients is:

$$
\begin{aligned}
E\left[W_{i} \mid D_{i}=0\right] & =\beta^{\prime} Z_{i}+E\left[\varepsilon_{i} \mid D_{i}=0\right] \\
& =\beta^{\prime} Z_{i}-\rho \sigma_{\varepsilon} \frac{\phi\left(\gamma^{\prime} X_{i}\right)}{1-\Phi\left(\gamma^{\prime} X_{i}\right)}
\end{aligned}
$$


The expected effect of poverty reduction associated with RPW (or PDS) is computed as (Greene, 2003, 787-789):

$$
\mathrm{E}\left[\mathrm{W}_{\mathrm{i}} \mid \mathrm{D}_{\mathrm{i}}=1\right]-\mathrm{E}\left[\mathrm{W}_{\mathrm{i}} \mid \mathrm{D}_{\mathrm{i}}=0\right]=\theta+\rho \sigma_{\varepsilon} \frac{\phi\left(\gamma^{\prime} \mathrm{X}_{\mathrm{i}}\right)}{\Phi\left(\gamma^{\prime} \mathrm{X}_{\mathrm{i}}\right)\left[1-\Phi\left(\gamma^{\prime} \mathrm{X}_{\mathrm{i}}\right)\right]}
$$

If $\rho$ is positive (negative), the coefficient estimate of $\theta$ using OLS is biased upward (downward) and the sample selection term will correct this. Since $\sigma_{\varepsilon}$ is positive, the sign and significance of the estimate of $\rho \sigma_{\varepsilon}$ (usually denoted as $\beta_{\lambda}$ ) will show whether there exists any selection bias. To estimate the parameters of this model, the likelihood function given by Maddala $(1983,122)$ is used where the bivariate normal function is reduced to the univariate function and the correlation $\rho$. The predicted values of (10) and (11) are derived and compared by the standard $t$ test to examine whether the average treatment effect or poverty reducing effect is significant.

The results of treatment effects model will have to be interpreted with caution because the results are sensitive to the specification of the model or the selection of explanatory variables and/or the instrument. Also important are the distributional assumptions of the model. However, applying the treatment effects model would overcome the potential limitation in propensity score matching to evaluate the impacts of RPW or PDS.

\section{(4) Propensity Score Matching Model}

Our main hypothesis is that the access of RPW (or PDS) reduces poverty (or undernutrition or vulnerability). Because we have only cross-sectional data, we can compare poverty status of households with access to RPW (or PDS) and those without, as long as RPW (or PDS) are randomly distributed across the sample. However, we cannot simply statistically compare the average of poverty or vulnerability measures for those with access to RPW (or PDS) and those without because of the sample selection bias. The sample selection problem may arise from (1) the self selection where the households themselves decide whether they should participate in Rural Public Works (or Public Distribution System), which depends on household observable and unobservable characteristics, and (2) the endogenous program placement where those who implement these programmes would select (a group of) households with specific characteristics (e.g. high poverty or low nutrition). The statistical 
matching, such as, PSM, could be used to take account of the sample selection bias or the endogeneity associated with the household access to RPW (or PDS.

The statistical matching has been widely used in the medical study where dose response of patients is analysed. The first stage specifies a function matching the proximity of one household to another in terms of household characteristics and then households are grouped to minimize the distance between matched cases in the second stage (Foster 2003). Merits of using statistical matching over the IV estimation includes; the former does not assume linearity; it is valid even though distributions of explanatory variables of treatment and control groups overlap relatively little, and it does not require a valid instrument. Rosenbaum and Rubin (1983) proposed statistical matching using the propensity score, the predicted probability that an individual receives the treatment of interest to make comparisons between individuals with the treatment and those without. Methodological issues and programs for propensity score matching estimation are discussed in details, for example, by Becker and Ichino (2002), Dehejia (2005), Dehejia and Wahba (2002), Smith and Todd (2005), Todd (2008) and Ravallion (2008).

While there are some advantages in using PSM to estimate the impact of the policy, the derived impact depends on the variables used for matching and the quantity and quality of available data and the procedure to eliminate any sample selection bias is based on observables (Ravallion 2008). If there are important unobservable variables in the model, the bias is still likely to remain in the estimates. For example, if the selection bias based on unobservables counteracts that based on observables, then eliminating only the latter bias may increase aggregate bias, while the replication studies comparing non-experimental evaluations, such as PSM, with experiments for the same programs do not appear to have found such an example in practice (ibid. 2008).

The discourse between Smith and Todd (2005) and Dehejia (2005) further draws our attention to the limitations of PSM in particular based on cross-sectional data. First, unmeasured characteristics or time effects cannot be controlled for by cross-sectional data. Second, bias associated with cross-sectional matching estimators may be large without a good set of covariates or if treated and control households are not strictly comparable, for example, located in different markets (Smith and Todd 2005). To partly overcome the limitation of PMS, we will also use the treatment effects model. 
We summarise below the estimation methods for the propensity score matching. The propensity score is the conditional probability of receiving a treatment (or of having access to RPW or PDS) given pre-treatment characteristics, X (or household characteristics).

$$
p(X)=\operatorname{Pr}\{D=1 \mid X\}=E\{D \mid X\}
$$

where $\mathrm{D}=\{0,1\}$ is the binary variable on whether a household has access to RPW (1) or not (0) and $\mathrm{X}$ is the multidimensional vector of pre-treatment characteristics or time-invariant or relatively stable household characteristics in our context. It was shown by Rosenbaun and Rubin (1983) that if the exposure to RPW is random within cells defined by X, it is also random within cells defined by $\mathrm{p}(\mathrm{X})$ or the propensity score.

The policy effect of RPW (or PDS) can be estimated in the same way as in Becker and Ichino (2002) as:

$$
\begin{aligned}
\tau & \equiv E\left\{W_{1 i}-W_{0 i} \mid D_{i}=1\right\} \\
& =E\left\{E\left\{W_{1 i}-W_{0 i} \mid D_{i}=1, p\left(X_{i}\right)\right\}\right\} \\
& =E\left\{E\left\{W_{1 i} \mid D_{i}=1, p\left(X_{i}\right)\right\}-E\left\{W_{0 i} \mid D_{i}=0, p\left(X_{i}\right)\right\} D_{i}=1\right\}
\end{aligned}
$$

where $i$ denotes the $i-t h$ household, $\mathrm{W}_{\mathrm{li}}$ is the potential outcome (e.g. poverty) in the two counterfactual situations with access to RPW (or PDS) and without.

The first line of the equation states that the policy effect is defined as the expectation of the difference of poverty or undernutrition of the $i$-th household with access to RPW and that for the same household in the counterfactual situation where it would not have had access to RPW. The second line is same as the first line except that the expected policy effect is defined over the distribution of the propensity score. The last line is the policy effect as an expected difference of poverty or undernutrition for the $i$-th household with access to RPW given the distribution of the probability of accessing RPW and that for the same household without RPW given the same distribution.

Formally, the following two hypotheses are needed to derive (14) given (13).

Lemma 1 Balancing Hypothesis (Balancing of pre-treatment variables given the propensity score)

If $\mathrm{p}(\mathrm{X})$ is the propensity score, then $D \perp X \mid p(X)$. 
This implies that given a specific probability of having access to RPW, a vector of household characteristics, $\mathrm{X}$ is orthogonal to (or uncorrelated to) the access to RPW. In other words, for a specific propensity score, the RPW is randomly distributed and thus on average households with RPW and those without are observationally identical (given a propensity score). Otherwise, one cannot statistically match households of different categories.

Lemma 2 Unconfoundedness given the propensity score

If treatment (or whether a household has access to RPW) is unconfounded, i.e. $W_{1}, W_{2} \perp D \mid X$

Then, assignment to treatment is unconfounded given the propensity score, i.e. $W_{1}, W_{2} \perp D \mid p(X)$

The latter implies that given a propensity score poverty or undernutrition is uncorrelated to the access to a RPW. If the above lemmas are satisfied, the policy effect can be estimated by the procedures described in Becker and Ichino (2002) and Smith and Todd (2005). Each procedure involves estimating probit model:

$$
\operatorname{Pr}\left\{\mathrm{D}_{\mathrm{i}}=1 \mid \mathrm{X}_{\mathrm{i}}\right\}=\Phi\left(\mathrm{h}\left(\mathrm{X}_{\mathrm{i}}\right)\right)
$$

where $\Phi$ denotes the logistic (or normal) cumulative distribution function (cdf) and $h\left(X_{\mathrm{i}}\right)$ is a starting specification. We use the probit model whereby whether a household has access to RPW is estimated by a vector of household and socio-economic characteristics. Because using a same set of the determinants of consumption would not only lead to the rejection of balancing hypothesis and but also be feasible with the large data, we take the minimalist approach where a considerably smaller number of explanatory variables are chosen.

One possible procedure for statistical matching is Stratification Matching whereby the sample is split in $k$ equally spaced intervals of the propensity score to ensure that within each interval the average propensity scores of treated and control households do not differ. We did not use Stratification Matching as observations are discarded when either treated or control units are absent. Instead, we use other variants in matching estimators of the average effect of treatment on the treated, namely, Nearest Neighbour Matching and Kernel Matching. ${ }^{15}$ Nearest Neighbour Matching is the method to take each treated unit and search for the control unit with the closest propensity score, while with Kernel Matching all treated are matched with a weighted average of all controls with weights that are inversely

${ }^{15}$ We did not use Radius Matching either as the results are sensitive to the predetermined radius. 
proportional to the distance between the propensity scores of treated and controls (see Becker and Ichino 2002 for details).

\section{(5) Pseudo Panel and IV Model}

One of the limitations in the above models is that each round of NSS is used separately for the cross-sectional estimations. To overcome this, we apply the pseudo panel model which aggregates micro-level household data by any meaningful unit or cohort (e.g. geographical areas or categorization by household characteristics) that is common across cross-sectional data sets in different years. We apply the pseudo panel model for the cohort $k$ based on the 78 NSS regions. The cohort is denoted as $k$ in the equation (16) below.

$$
\bar{W}_{i k t}=\alpha+\bar{X}_{i k t} \beta_{1}+\beta_{2}{\overline{D_{i k t}}}_{\gamma}+\gamma T_{t}+\mu_{i}+e_{k t}
$$

where $k$ denotes cohort (i.e., NSS region) and $t$ stands for survey years for three rounds of NSS, 1993 and 2005. The upper bar means that the average of each variable is taken for each cohort, $k$ for each round $t . \bar{W}_{i k t}$ is thus the regional average of poverty measure (undernutrition or vulnerability measure), $\bar{X}_{i k t}$ is a vector of the average of household and other characteristics, $\bar{D}_{i k t}$ is the average of access to RPW (or PDS), $T_{t}$ is a time dummy variable, $\bar{\mu}_{k t}$ is the unobservable fixed or random effect at cohort level and $\bar{e}_{k t}$ is the error term.

$$
\bar{W}_{i k t}=\alpha+\bar{X}_{i k t} \beta_{1}+\beta_{2}{\overline{D_{i k t}}}+\gamma T_{t}+\bar{\mu}_{k t}+\bar{e}_{k t}
$$

The equation (17) can be estimated by the standard static panel mode, such as fixed effects or random effects model. The issue is whether the equation (17) is a good approximation of the underlying household panel models for household $i$ in the equation (17)' below.

$$
W_{i t}=\alpha+W_{i t} \beta_{1}^{\prime}+\beta_{2}^{\prime} D_{i t}+\gamma^{\prime} T_{t}+\mu_{i t}^{\prime}+e_{i t}
$$

It is not straightforward to check this as we do not have 'real' panel data. However, as shown by Verbeek and Nijman (1992) and Verbeek (1996), if the number of observations in cohort $k$ tends to infinity, $\bar{\mu}_{k i} \rightarrow \mu_{k}{ }^{*}$ and the estimator is consistent. In our case, $k$ is very large and thus the estimator is likely to be almost consistent. Once we take account of the cohort population, the equation (17) will become the model developed by Deaton (1985) whereby $\bar{n}_{x_{k t}}$ and $\bar{x}_{\mathrm{z}_{k t}}$ are considered to be error-ridden measurements of unobservable cohort means, which leads to so-called 'error-in-variables estimator' (see Fuller, 1987 for more details). As an extension, because RPW or PDS could be endogenous, we apply G2SLS 
random-effects IV regression where $\overline{D_{i k t}}$ is instrumented by either the average wages or food price index.

\section{Results}

In this section we will summarise key findings obtained from the econometric estimations of the models we described in the last section.

\section{Vulnerability Estimates}

Table 1 presents the regression results for vulnerability estimations for NSS 50 (1993-4) and NSS 61 (2004-5). The results for consumption (equation (2)) or log mean per capita expenditure (MPCE) (equation (3)) are reported. A few results are surprising contrary to the intuition. For example, in 1993, the coefficient estimate of the number of adult female members is negative and highly significant, that of being headed by a female member is positive and significant Both are negative and significant in 2004. The proportion of adult members is positive and highly significant in 1993 and 2004, reflecting the negative effects of dependency burden on children and the elderly on per capita consumption. While the age of the household head is negative and significant to explain per capita household expenditure in 1993 with significant non-linear effect suggested by positive and significant coefficient estimate of its square, the signs are opposite in 2004. Higher levels of educational attainment are positively and significantly associated with higher per capita consumption in both 1993 and 2004. Dummy variables associated with larger areas of land owned are also positively associated with per capita expenditure in 1993 and 2004. Dummy variables on household head's occupation show the similar pattern of the results for two rounds. Belonging to Schedule Castes (SC) or Schedule Tribe (ST) is negative and highly significant in 1993 and 2004. While the results of state dummies are omitted from the table, they indicate the high degree of geographical differences in household consumption in 1993 and 2004.

\section{(Table 1 to be inserted)}

Table 1 also shows the results of variance of log mean per capita expenditure. Female member's headedness of the household is positively and significantly associated with higher variance in consumption in 1993 and 2004, implying the wider range of (conditional) distribution of consumption for female headed household than for male headed household. 
Thus, the possibility is not precluded that some female headed households have very low consumption in 1993. Higher level of educational attainment of household members and larger land holding (more than 2.5 hectares) seems associated with higher consumption variance in both years. Not being agricultural labourers or not belonging to SC or ST is associated with higher variance of consumption. These estimation results are used to derive vulnerability measures.

Appendix 3 presents the results for the wage equations for male and female workers based on the employment schedule of NSS $50^{\text {th }}$ and 61 at rounds. While most of the results are expected, a few unexpected results are also found. For example, owned land of the household which the worker belongs to is negatively associated with female wages in both 1993 and 2004 and land area is positively associated with male wages with significant coefficient estimate for 2004 and not significant for 1993. The underlying reasons are not clear, but it could be due to the fact that men's ownership of land may serve as a source for better wage through the bargaining with the employers or that only men can control household assets, including land. The coefficients for ST or SC are negative and significant in determining wages. Workers in the households classified as non-agricultural or agricultural self employed tend to have higher wages. Age is positive significant, while its square is negative and significant in both years. Because there are not many observations for female wages and they are not significant in the equation of RPW, we use predicted male wage as an instrument for the participation equation in RPW.

\section{Treatment-effects Model}

Table 2 and Table 3 present the results of treatment effects model. Table 2 report the regression results in the first stage whereby either the access to RPW or PDS is estimated by probit model (for the equation (8)) and those in the second stage for the equation of poverty (or vulnerability or undernourishment) taking account of sample selection bias (for the equation (8)). Table 3 summarises the treatment effects for various cases. Four cases are highlighted in Tables 2, 3 and 4, namely, Case 1- the case where the treatment effect of RPW is estimated by NSS 50 ${ }^{\text {th }}$ round in 1993; Case 2- the case for PDS in 1993 or NSS 50; Case 3the case for RPW (where it is proxied by FFW, a version of RPW due to the data constraints) in 2004 or NSS 61; and Case 4- the case for PDS in 2004 or NSS 61.

(Table 2 and Table 3 to be inserted) 
We will briefly explain the determinants of participation in RPW and the access to PDS in 1993 and 2004. Female member headedness of the household is a negative and significant determinant of RPW participation in Cases 1 and 3 and a positive determinant of PDS access, which is significant in Case 4. The more female adult members, the more likely it is for a household to have access to PDS (Cases 2 and 4). The more male adult member would drive the household to participate in RPW in 1993 and 2004 and to access PDS in 2004. The dependency burden is positively and significantly associated with the PDS access, as suggested by the negative coefficient estimates for the share of adult members in the household. The household with an older head is more likely to have access to PDS in 1993 and 2004. Education dummies are negative and significant in most of the cases, which implies the household with lower levels of educational attainment or without literate members tends to access RPW and PDS. This is an indirect evidence of good targeting performances of these schemes. The households with the owned land area from 0.1 to 2.5 hectares are more likely to participate in RPW than the landless or those with the land larger than 2.5 hectares in 1993 and 2004 (Cases 1 and 3). Whilst the landless is more likely to have access to PDS than those with land in 1993 (Case 2), those with the land area from 0.1 to 2.5 hectares are more likely to access PDS than the rest in 2004 (Case 4). The agricultural or non-agricultural labourer tends to join RPW and PDS. The schemes are more likely to be utilised by those belonging to SCs or STc. While predicted male wage is positive and significant in 1993, it is negative and highly significant in 2004 in the RPW participation equation. The coefficient estimate of food price index is positive and significant in the PDS equation.

Table 2 reports the results of the second-stage regressions where the dependent variable is (a) consumption-based poverty (in the first panel of the second stage results), (b) vulnerability estimate (in the second panel), and (c) undernutrition based on calorie and protein only for NSS $50^{\text {th }}$ round (in the third panel). We only summarise the key results. First, the coefficient of $\beta_{\lambda}$, the degree of sample selection is significant in all the cases (most of which are negative as in Cases 1, 2, and 4 in (a) consumption-based poverty, in Cases 1 to 4 in (b) vulnerability, the first and the third columns of RPW for (c) nutrition-based poverty. The actual poverty reducing effects are affected by the sample selection effects and direct effects of the schemes, $\theta$. The treatment effects are calculated and summarised in Table 3. 
The comparison of determinants of (a) consumption-based poverty, (b) vulnerability estimate, and (c) undernutrition based on calorie and protein for the cases of RPW and PDS would be of empirical significance in itself. Overall, the determinants of poverty, vulnerability and undernutrition are similar with a few exceptions. Female member headedness is considered to be a factor of increasing the probability of being poor, but we observe a negative and significant coefficient estimate in Case 2 (NSS50) of consumption poverty, Case 1 (NSS50) of vulnerability, and Case 1 of calorie poverty and Case 2 of protein poverty for NSS50. Household composition is significantly associated with poverty, vulnerability and undernutrition. For example, they are negatively affected by dependency burden or the number of adult female members in the household. The household with an older household head is more likely to be poor with some non-linear effect with an exception of Case 2 in (c), calorie based poverty which shows the positive sign. The higher levels of educational attainment and the larger land area tends to decrease the probability of being poor, vulnerable and undernourished. Belonging to SCs or STs is highly correlated with not only poverty, but also vulnerability and undernutrition.

Table 3 summarises the treatment effects associated with RPW and PDS. RPW decreases consumption-based poverty and protein-based significantly in 1993, but not calorie-based poverty as shown by Case 1 . This might reflect the fact that RPW is sometimes physically demanding and requiring calorie to perform tasks. In 1993, significant vulnerability reducing effects are observed only for the vulnerability which is calculated based on $80 \%$ of the national poverty line (and the effects are positive for $100 \%$ and $120 \%$ ). In 2004, RPW is confirmed to have significant impact on reducing poverty and vulnerability. On the contrary, PDS significantly increased consumption-based poverty and nutrition-based poverty in 1993 and consumption-based poverty in 2003 (Cases 2 and 4). However, PDS significantly decreased vulnerability in both 1993 and 2003. This may reflect the aspect of social protection in PDS.

\section{Propensity Score Matching}

Because of the difficulty of obtaining the convergence and the tendency to violate the balancing hypothesis, we have taken the minimalist approach and have avoided using the binary variable in estimating PSM models. We have kept the number of adult male members, the proportion of adults in the household, age of the household head, land per capita, and 
predicted male wages (only for RPW) and Food Price Index (only for PDS). The results are shown in Table 4. The distributions of propensity scores are presented in Appendix 4.

\section{(Table 4 to be inserted)}

Table 4 summarises the final results of PSM. The results are sensitive to our choice of the method of matching, Kernel matching or Nearest Neighbour matching.

In Case 1 where we analyse the effects of RPW on poverty, undernutrition and poverty in 1993, we observe a significant poverty reducing effect on calorie based poverty in case where Nearest Neighbour matching is used. It is not significant in the case where Kernel matching is used. However, significantly negative impacts of household participation in RPW are found on vulnerability in Case 1 for both Kernel matching or Nearest Neighbour matching.

In Case 3 for RPW in 2004, we find a significant poverty reducing effect on consumption-based poverty in case of Kernel matching method. The average treatment effect is negative, but not significant when Nearest Neighbour matching is applied. Again, RPW reduces vulnerability significantly in 2004 .

In Case 2 for the evaluation of PDS in 1993, the average treatment effect is positive and not significant except one case of Nearest Neighbour matching for consumption-based poverty. In Case 4, we find a poverty-increasing effect of PDS on consumption-based poverty when Kernel matching is used. As long as we use the static indicators of poverty, PDS appears to increase poverty. However, once we use the vulnerability measures, we find significant poverty-reducing effects of PDS in 1993 and 2004. The results obtained by PSM are broadly consistent with those of treatment-effects model.

\section{State-wise results}

One of the major limitations of PSM and treatment-effects model is that neither of the models takes account of heterogeneity within the sample. Because of the large country size, the concern would arise on the geographical diversity of the results. In the previous regression models, we have included state dummy variables to consider this. However, dummy variables only capture the difference of constant in the regression, not the difference of the slope. We 
have thus applied treatment-effects model for the Indian states with reasonably large number of observations for NSS-50 and NSS-61. The results are shown in Table 5.

\section{(Table 5 to be inserted)}

The states with negative average treatment effect are shown in bold in Table 5, which shows a significant degree of diversity among different states. For example, while RPW has a negative and significant effect to reduce poverty in 1993, the significant and negative effects of RPW are observed in only several states, such as Rajasthan, Orissa, Madhya Pradesh and Tamil Nadu. While we observe a positive and significant effect of PDS on poverty for all India in 1993, the effects are negative and significant in Andhra Pradesh, Kerala, and Tamil Nadu.

The pattern of diversity differs considerably once we focus on vulnerability. While RPW increases vulnerability for all India, negative and significant average treatment effects of RPW are observed for Punjab, Orissa, and Tamil Nadu in 1993. The negative and significant effects of PDS on vulnerability are found only for Punjab, Madhya Pradesh and Kerala despite the negative and significant estimate for all India.

For NSS 61 in 2004, we found a negative and significant average treatment effect of RPW on poverty for all India. However, the state-wise results show that the treatment effects are significant and negative only in Punjab, Haryana, West Bengal, Maharashtra and Andhra Pradesh. Many of other states show the positive and significant treatment effects. PDS, on the other hand, has a positive and significant treatment effect on poverty for all India with a significant degree of diversity. Punjab, West Bengal and Madhya Pradesh are among the states with a negative and significant treatment effect of PDS on poverty.

It is found that RPW reduces vulnerability significantly for all India in 2005, many states show positive and significant treatment effects. The negative and significant effects are found only for Bihar, West Bengal and Kerala. On the other hand, the average effect of PDS on vulnerability is negative and significant in most of the states in 2005 with exceptions of Haryana and Tamil Nadu which show positive and significant effects. 


\section{Pseudo Panel Model}

The results based on IV regression for pseudo panel data model are reported in Table 6 . The results have to be interpreted with caution in particular because the instrument for RPW, aggregation of predicted wages is not significant in the first stage. Focusing on the coefficient estimates of RPW or PDS that is instruments, we do not find any significant results except one case where PDS reduces vulnerability significantly at 5\% level when it is defined based on $80 \%$ of the poverty threshold. This is consistent with the earlier results of treatment effects model.

\section{(Table 6 to be inserted)}

\section{Conclusion}

This paper analyses the effects of access to Rural Public Works (RPW) and Public Distribution System (PDS), a public food subsidy programme, on consumption poverty, vulnerability and undernutrition in India drawing upon the large household data sets constructed by National Sample Survey (NSS) data, 50 ${ }^{\text {th }}$ round in 1993-1994 and $61^{\text {st }}$ round in 2004-2005. Vulnerability is defined as the probability of a household falling into poverty and is estimated using the methodology out forward by Chaudhuri (2003) and Chaudhuri et al. (2002). Undernutrition measures are derived by converting the detailed expenditure data into the nutritional equivalent of calorie intakes or protein.

The need has arisen to take account of sample selection in evaluating policy effects because the access to RPW or PDS is not randomly distributed across the sample due to the self selection where a household opts to take up the programme in light of its specific characteristics or circumstances (e.g. hunger, lack of human resources) and/ or the endogenous programme placement, that is, policy makers select, for example, geographical areas in reflection of policy needs (e.g. poverty reduction). Treatment-effects model, a version of Heckman sample selection model and Propensity Score Matching (PSM) Model are used, at least partly, to take account of the sample selection bias in evaluating the effects of RPW or PDS on poverty. The results, however, will have to be interpreted with caution because of the presence of unobservable factors which are important in decision making to participate in RPW or access PDS which cannot be controlled by the survey data. 
We have found significant and negative effects of the household participation in Rural Public Works and Food for Work Programmes on poverty, undernutrition (e.g. protein) and vulnerability in 1993 and 2004. Broadly similar results have been obtained by treatment-effects model and PSM. However, once we apply the treatment effects model separately for each state, a great degree of diversity is observed. Also, we do not find any significant results for RPW in pseudo panel data models.

On the contrary, the prevalence of poverty and undernutrition is significantly higher for the households with access to PDS than those without. However, PDS has significant effects on reducing vulnerability of households in 1993 and 2004, which has been confirmed by treatment-effects model and PSM. The effects of PDS are different among different results. PDS decreased vulnerability based on $80 \%$ of the poverty threshold in IV model applied to pseudo panel.

\section{References}

Becker, S. and Ichino, A. (2002), 'Estimation of Average Treatment Effects based on Propensity Scores,' The Stata Journal, 2(4), 358-377.

Besley, T. and Coate, S. (1992) 'Workfare versus Welfare: Incentive Arguments for Work Requirements in Poverty Alleviation Programs', American Economic Review, 82 (1), 249- 261.

Bhalotra, S. (2002) 'Welfare Implications of Fiscal Reform: The Case of Food Subsidies in India', UNU-WIDER Discussion Paper No. 2002/32, March 2002.

Chaudhuri, S. (2003) Assessing vulnerability to poverty: concepts, empirical methods and illustrative examples, mimeo., Columbia University.

Chaudhuri, S., Jalan, J. and Suryahadi, A. (2002) Assessing Household Vulnerability to Poverty from Cross-Sectional Data: A Methodology and Estimates from Indonesia. Discussion Paper, Columbia University.

Dasgupta, P. (1997) 'Nutritional status, the capacity for work, and poverty traps', Journal of Econometrics, 77(1), 5-37.

Deaton, A. (1985) 'Panel Data from the Time Series of Cross-Sections', Journal of Econometrics 30, 109-126. Deaton, A. and Tarozzi, A. (2000) 'Prices and poverty in India', Draft, Research Program in Development Studies, Princeton University (July 2000).

Dehejia, R. (2005) 'Practical Propensity Score Matching: a Reply to Smith and Todd,' Journal of Econometrics, 125, 355-364.

Dehejia, R., and Wahba, S. (2002) 'Propensity Score Matching Methods for Nonexperimental Causal Studies', Review of Economics and Statistics, 84 (1), 151-161.

Foster, M. (2003) 'Propensity Score Matching: An Illustrative Analysis of Dose Response', Medical Care, 41(10), 1183-1192.

Fuller, W. A. (1987) Measurement Error Models, Wiley and Sons: New York. 
Gaiha, R. and Imai, K. (2009) 'Measuring Vulnerability and Poverty in Rural India', forthcoming, Chapter 2 in W. Naudé, A. Santos-Paulino and M. McGillivray (Eds.) Dimensions of Vulnerability: Risk and Poverty in Developing Countries, Helsinki: UNU press.

Gaiha, R., Imai, K. and Kaushik, P.D., (2001) 'On the Targeting and Cost-effectiveness of Anti-Poverty Programmes in Rural India', Development and Change, 32, pp. 309-342.

Gaiha, R., Thapa, G., Imai, K., and Kukkarni, V., (2007) 'Endowments, Discrimination and Deprivation among Ethnic Groups in Rural India', Economics Discussion Paper, University of Manchester $(0722,2007)$.

Greene, W. H. (2003) Econometric Analysis $5^{\text {th }}$ edition, Upper Saddle River, NJ, Prentice-Hall.

Hoddinott, J., and Quisumbing, A. (2003a) Data Sources for Microeconometric Risk and Vulnerability Assessments. Social Protection Discussion Paper Series No.0323, The World Bank.

Hoddinott, J., and Quisumbing, A. (2003b) Methods for Microeconometric Risk and Vulnerability Assessments. Social Protection Discussion Paper Series No.0324, The World Bank.

Foster, A. (1995) Household Savings and Human Investment Behaviour in Development, Nutrition and Health Investment, The American Economic Review, 85, 148-152.

Gopalan, C. (1992) "Undernutrition: Measurement and Implications", in S. Osmani (ed.) Nutrition and Poverty, New Delhi, Oxford University Press.

Gopalan, C., Sastri, B.V.R. and S.C. Balasubramanian (1971) "Nutritive Value of Indian Foods" Hyderabad: National Institute of Nutrition.

Heckman, J. (1979), "Sample selection bias as a specification error,” Econometrica, 47, 153-61.

Himanshu, (2007) 'Recent Trends in Poverty and Inequality: Some Preliminary Results', Economic and Political Weekly, 10 February 2007, 498-508.

Jha, R. and Gaiha, R., (2003) 'Determinants of undernutrition in rural India' RSPAS Working Paper Series 2003-1., Australian National University.

Kijima, Y., (2006) 'Caste and Tribe Inequality: Evidence from India, 1983-1999,' Economic Development and Cultural Change, University of Chicago Press, 54 (2), 369-404, January.

Maddala, G. S. (1983), Limited-dependent and Qualitative Variables in Econometrics, Cambridge, Cambridge University Press.

Ravallion, M. (2008), 'Evaluating Anti-Poverty Programme', Chapter 59 in Handbook of Development Economics, Volume 4, P. Schultz and J. Strauss (Eds), Elsevier.

Rosenbaum, P.R., and Rubin, D.B. (1983) 'The Central Role of the Propensity Score in Observational Studies for Causal Effects', Biometrica, 70(1), 41-55.

Smith, J. A., and Todd, P. E. (2005) 'Does Matching Overcome LaLonde's Critique of Nonexperimental Estimators?' Journal of Econometrics, 125, 305-353.

Todd, P. E. (2008), 'Evaluating Social Programs with Endogenous Program Placement and Selection of the Treated', Chapter 60 in Handbook of Development Economics, Volume 4, P. Schultz and J. Strauss (Eds), Elsevier.

Verbeek, M.(1996) Pseudo Panel Data. in Matyas, L, Sevestre, P. (Eds.), The econometrics of panel data: A handbook of the theory with applications, second edition, in Advanced Studies in Theoretical and Applied Econometrics, vol. 33. Dordrecht; Kluwer Academic: Boston and London, 280-92.

Verbeek, M. And Nijman T. E. (1992) Can Cohort Data Be Treated As Genuine Panel Data? Empirical Economics, 17, 9-23. 
Table 1 Estimation of Vulnerability Equations

\begin{tabular}{|c|c|c|c|c|c|c|c|c|c|c|c|c|}
\hline & \multicolumn{6}{|c|}{ NSS 50 (1993-1994) } & \multicolumn{6}{|c|}{ NSS 61 (2004-2005) } \\
\hline & \multicolumn{6}{|c|}{ Consumption } & \multicolumn{6}{|c|}{ Consumption } \\
\hline & \multicolumn{3}{|c|}{$\log (\mathrm{MPCE})$} & \multicolumn{3}{|l|}{ Variance } & \multicolumn{3}{|c|}{$\log (M P C E)$} & \multicolumn{3}{|l|}{ Variance } \\
\hline & Coef. & $T$ & & Coef. & $\mathrm{t}$ & & Coef. & $\mathrm{t}$ & & Coef. & $\mathrm{t}$ & \\
\hline Whether a household is headed by a female member & 0.205 & $(24.15)$ & * & 0.439 & $(12.31)$ & ** & -0.021 & $(-3.67)$ & ** & 0.230 & $(8.09)$ & \\
\hline Number of adult female members & -0.325 & $(-98.54)$ & *t & -0.027 & $(-2.28)$ & * & -0.123 & $(-51.36)$ & ** & -0.049 & $(-4.08)$ & * \\
\hline Number of adult male members & -0.261 & $(-89.61)$ & * & 0.061 & $(5.25)$ & ** & -0.101 & $(-43.24)$ & ** & -0.025 & $(-2.10)$ & * \\
\hline The proportion of adults in a household & 2.177 & $(222.41)$ & ** & 0.260 & $(6.05)$ & ** & 0.627 & $(81.53)$ & ** & -0.063 & $(-1.62)$ & \\
\hline Age of household head & -1.010 & $(-10.19)$ & * & -3.366 & $(-8.74)$ & ** & 0.560 & $(7.52)$ & ** & -0.814 & $(-2.10)$ & * \\
\hline Age squared & 1.052 & $(10.30)$ & * & 3.475 & $(8.67)$ & ** & -0.250 & $(-3.33)$ & * & 1.184 & $(3.05)$ & $*$ \\
\hline The max. education of adult (Primary) & 0.125 & $(20.15)$ & ** & 0.078 & $(2.62)$ & * & 0.081 & (18.09) & ** & -0.058 & $(-2.23)$ & \\
\hline The max. education of adult (Middle) & 0.211 & $(29.58)$ & ** & 0.163 & $(5.14)$ & ** & 0.197 & $(45.30)$ & ** & 0.069 & $(2.85)$ & * \\
\hline The max. education of adult (>=Matriculates) & 0.392 & (51.19) & * & 0.309 & $(9.50)$ & ** & 0.416 & $(74.64)$ & ** & 0.328 & $(11.49)$ & $*$ \\
\hline Land $(0.1<=2.5 \mathrm{ha})$ (default: the landless) & 0.129 & $(22.93)$ & *t & 0.064 & $(2.43)$ & * & 0.051 & (13.37) & ** & -0.048 & $(-2.37)$ & * \\
\hline Land (>2.5 ha) (default: the landless) & 0.503 & $(8.11)$ & $*$ & 0.298 & $(1.40)$ & & 0.273 & (39.42) & ** & 0.158 & $(4.49)$ & ** \\
\hline Whether self-employed in non-agriculture & -0.076 & $(-8.60)$ & ** & -0.082 & $(-2.15)$ & * & -0.118 & $(-21.33)$ & ** & -0.032 & $(-1.15)$ & \\
\hline Whether agricultural labour & -0.266 & $(-34.27)$ & $*$ & -0.299 & $(-8.73)$ & ** & -0.318 & $(-52.90)$ & ** & -0.329 & $(-10.33)$ & * \\
\hline Whether non-agricultural labour & -0.176 & $(-18.03)$ & * & -0.207 & $(-4.58)$ & ** & -0.241 & $(-37.52)$ & ** & -0.201 & $(-5.99)$ & * \\
\hline Whether self-employed in agriculture & -0.078 & $(-10.13)$ & * & -0.156 & $(-4.72)$ & ** & -0.129 & $(-24.63)$ & ** & -0.132 & $(-4.91)$ & $*$ \\
\hline Whether a household belongs to SC (Scheduled Caste) & -0.178 & $(-27.18)$ & * & -0.015 & $(-0.44)$ & & -0.156 & $(-32.62)$ & ** & -0.088 & $(-3.17)$ & * \\
\hline Whether a household belongs to ST (Scheduled Tribe) & -0.116 & $(-23.60)$ & $*$ & -0.039 & $(-1.59)$ & & -0.102 & $(-25.19)$ & ** & -0.092 & $(-4.04)$ & ** \\
\hline Constant & 8.833 & $(329.31)$ & & -2.434 & $(-22.69)$ & & 9.741 & $(489.22)$ & & -2.992 & $(-27.98)$ & \\
\hline Number of obs & & 58664 & & & 58664 & & & 78873 & & & 78873 & \\
\hline$F(31,58632)$ & & 2610 & & & 41 & & $\begin{array}{l}F(51, \\
78821)\end{array}$ & 1065 & & & 45 & \\
\hline Prob $>$ F & & 0 & & & 0 & & & 0 & & & 0 & \\
\hline Root MSE & & 0 & & & 2 & & & 0 & & & 2 & \\
\hline
\end{tabular}

${ }^{* *}=$ significant at $1 \%$ level. ${ }^{*}=$ significant at $5 \%$ level. +=significant at $10 \%$ level. 
Table 2 Treatment Effects Model (Regression Results)

\begin{tabular}{|c|c|c|c|c|c|c|c|c|c|c|c|c|}
\hline \multirow[t]{4}{*}{ 1st Stage Probit } & Case 1 & \multicolumn{4}{|c|}{ Case 2} & \multicolumn{2}{|r|}{ Case 3} & \multicolumn{5}{|c|}{ Case 4} \\
\hline & NSS50 & & & NSS50 & & & NSS61 & & & NSS61 & & \\
\hline & RPW & & & PDS & & & RPW & & & PDS & & \\
\hline & Coef. & z & & Coef. & Z & & Coef. & z & & Coef. & z & \\
\hline Whether a household is headed by a female member & -0.172 & $(-4.22)$ & 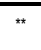 & 0.034 & $(1.40)$ & & -0.107 & $(-2.46)$ & $*$ & 0.039 & $(2.10)$ & * \\
\hline Number of adult female members & -0.003 & $(-0.27)$ & & 0.056 & (6.91) & $*$ & 0.022 & $(1.29)$ & & 0.105 & $(13.07)$ & ** \\
\hline Number of adult male members & 0.047 & $(4.18)$ & $*$ & 0.009 & $(1.16)$ & & 0.080 & $(4.89)$ & $*$ & 0.039 & $(5.15)$ & $*$ \\
\hline The proportion of adults in a household & -0.053 & $(-1.21)$ & & -0.192 & $(-6.37)$ & $*$ & -0.091 & $(-1.68)$ & + & -0.375 & $(-15.28)$ & $*$ \\
\hline Age of household head & 0.406 & $(1.04)$ & & 1.755 & $(6.42)$ & $*$ & -0.663 & $(-1.24)$ & & 3.397 & $(13.90)$ & ** \\
\hline Age squared & -0.513 & $(-1.26)$ & & -1.606 & $(-5.67)$ & * & 0.614 & $(1.12)$ & & -2.854 & $(-11.60)$ & ** \\
\hline The max. education of adult (Primary) & -0.091 & $(-2.87)$ & $*$ & -0.022 & $(-1.10)$ & & -0.065 & $(-2.13)$ & * & 0.011 & $(0.63)$ & \\
\hline The max. education of adult (Middle) & -0.094 & $(-2.73)$ & $*$ & -0.046 & $(-2.06)$ & $*$ & -0.211 & $(-6.77)$ & $*$ & -0.062 & $(-3.91)$ & ** \\
\hline The max. education of adult (>=Matriculates) & -0.055 & $(-1.61)$ & & -0.112 & $(-4.90)$ & $*$ & -0.466 & $(-10.45)$ & $*$ & -0.228 & $(-12.32)$ & $*$ \\
\hline Land (0.1<=2.5 ha) (default: the landless) & 0.055 & $(2.05)$ & * & -0.158 & $(-8.56)$ & $*$ & 0.100 & $(3.71)$ & $*$ & 0.190 & $(14.29)$ & $*$ \\
\hline Land (>2.5 ha) (default: the landless) & -0.059 & $(-0.23)$ & & -0.308 & $(-1.89)$ & + & -0.066 & $(-1.33)$ & & -0.029 & $(-1.30)$ & \\
\hline Whether self-employed in non-agriculture & -0.095 & $(-2.28)$ & * & 0.070 & $(2.74)$ & $*$ & 0.496 & $(8.43)$ & $*$ & 0.206 & $(11.74)$ & * \\
\hline Whether agricultural labour & 0.093 & $(2.66)$ & $*$ & 0.102 & $(4.48)$ & * & 1.023 & $(17.32)$ & * & 0.350 & (16.81) & * \\
\hline Whether non-agricultural labour & 0.247 & $(5.71)$ & $*$ & 0.200 & $(6.77)$ & $*$ & 1.112 & $(18.79)$ & $*$ & 0.268 & $(12.18)$ & * \\
\hline Whether self-employed in agriculture & -0.082 & $(-2.37)$ & $*$ & -0.067 & $(-2.99)$ & $*$ & 0.691 & $(12.41)$ & $*$ & 0.137 & $(7.95)$ & ** \\
\hline Whether a household belongs to SC (Scheduled Caste) & 0.156 & $(5.15)$ & $*$ & 0.098 & $(4.50)$ & * & 0.285 & $(9.50)$ & $*$ & -0.015 & $(-0.82)$ & \\
\hline Whether a household belongs to ST (Scheduled Tribe) & 0.078 & (3.13) & $*$ & 0.025 & (1.41) & & 0.105 & $(3.53)$ & * & 0.092 & $(5.92)$ & * \\
\hline Predicted male wages (at NSS region) & 0.002 & $(2.54)$ & * & - & - & & -0.086 & $(-34.92)$ & $*$ & - & - & \\
\hline Food Price Index & - & - & & 0.061 & $(32.14)$ & * & - & - & & 0.156 & $(19.10)$ & * \\
\hline Constant & -2.248 & $(-17.83)$ & $*$ & -7.632 & $(-35.42)$ & $*$ & 0.643 & $(3.70)$ & & -2.246 & $(-18.50)$ & \\
\hline Number of obs & & 58664 & & & 58663 & & & 76686 & & & 78873 & \\
\hline LR chi2(52) & & 442 & & LR chi2(31) & 13637 & & LR chi2(42) & 5477 & & & 16624 & \\
\hline Prob > chi2 & & 0 & & & 0 & & & 0 & & & 0 & \\
\hline Pseudo R2 & & 0 & & & 0 & & & 0 & & & 0 & \\
\hline Log likelihood & & -9804 & & & -24761 & & & -7537 & & & -36841 & \\
\hline
\end{tabular}




\begin{tabular}{|c|c|c|c|c|c|c|c|c|c|c|c|}
\hline \multirow[t]{4}{*}{ 2nd Stage (a) } & Case 1 & \multicolumn{4}{|c|}{ Case 2} & \multicolumn{3}{|c|}{ Case 3} & Case 4 & \multirow[b]{4}{*}{ z } & \\
\hline & NSS50 & \multirow[b]{3}{*}{$\mathrm{z}$} & \multicolumn{2}{|r|}{ NSS50 } & & \multicolumn{2}{|r|}{ NSS61 } & \multicolumn{3}{|c|}{ NSS61 } & \\
\hline & RPW & & \multicolumn{3}{|c|}{ PDS } & \multicolumn{3}{|c|}{ RPW } & \multicolumn{2}{|l|}{ PDS } & \\
\hline & Coef. & & & Coef. & Z & & Coef. & $\mathrm{z}$ & Coef. & & \\
\hline poor (consumption) & \multicolumn{2}{|c|}{ poor (consumption) } & & \multicolumn{2}{|c|}{ poor (consumption) } & & \multicolumn{2}{|c|}{ poor (consumption) } & $\begin{array}{c}\text { poor } \\
\text { (consumption) }\end{array}$ & & \\
\hline Whether a household is headed by a female member & -0.007 & $(-1.15)$ & & -0.014 & $(-2.26)$ & * & 0.010 & (2.39) & * $\quad 0.011$ & (2.61) & " \\
\hline Number of adult female members & 0.010 & $(4.86)$ & * & 0.011 & $(5.59)$ & $*$ & 0.055 & $(29.57)$ & 0.058 & $(29.60)$ & ** \\
\hline Number of adult male members & 0.022 & $(10.75)$ & $*$ & 0.024 & $(12.74)$ & $*$ & 0.037 & $(20.81)$ & 0.039 & $(22.14)$ & * \\
\hline The proportion of adults in a household & -0.026 & $(-3.44)$ & $*$ & -0.034 & $(-4.51)$ & $*$ & -0.306 & $(-52.01)$ & -0.318 & $(-49.50)$ & $*$ \\
\hline Age of household head & -0.511 & $(-7.79)$ & $*$ & -0.441 & $(-6.78)$ & $*$ & -0.164 & $(-2.79)$ & -0.036 & $(-0.56)$ & \\
\hline Age squared & 0.492 & $(7.23)$ & $*$ & 0.421 & $(6.28)$ & $*$ & -0.024 & $(-0.40)$ & -0.131 & $(-2.11)$ & * \\
\hline The max. education of adult (Primary) & -0.039 & $(-7.49)$ & $*$ & -0.044 & $(-8.81)$ & $*$ & -0.067 & $(-16.96)$ & -0.068 & $(-17.21)$ & * \\
\hline The max. education of adult (Middle) & -0.059 & $(-10.49)$ & $*$ & -0.065 & $(-12.00)$ & $*$ & -0.129 & $(-34.52)$ & -0.135 & $(-36.14)$ & * \\
\hline The max. education of adult (>=Matriculates) & -0.110 & $(-19.53)$ & $*$ & -0.116 & $(-21.05)$ & $*$ & -0.173 & $(-39.05)$ & -0.186 & $(-39.99)$ & * \\
\hline Land ( $0.1<=2.5$ ha) (default: the landless) & -0.032 & $(-6.97)$ & * & -0.034 & $(-7.29)$ & $*$ & -0.031 & $(-9.90)$ & -0.021 & $(-6.39)$ & ** \\
\hline Land (>2.5 ha) (default: the landless) & -0.057 & $(-1.41)$ & & -0.069 & $(-1.75)$ & + & -0.106 & $(-19.80)$ & -0.108 & $(-20.17)$ & ** \\
\hline Whether self-employed in non-agriculture & -0.003 & $(-0.51)$ & & -0.005 & $(-0.84)$ & & 0.041 & $(9.78)$ & 0.051 & $(11.51)$ & * \\
\hline Whether agricultural labour & 0.072 & $(12.02)$ & * & 0.081 & $(13.77)$ & $*$ & 0.158 & $(31.53)$ & 0.182 & $(33.29)$ & * \\
\hline Whether non-agricultural labour & 0.037 & $(4.39)$ & $*$ & 0.059 & $(7.37)$ & $*$ & 0.081 & $(14.93)$ & 0.105 & $(19.12)$ & * \\
\hline Whether self-employed in agriculture & -0.010 & $(-1.66)$ & + & -0.016 & $(-2.77)$ & $*$ & 0.017 & $(4.04)$ & 0.027 & $(6.46)$ & * \\
\hline Whether a household belongs to SC (Scheduled Caste) & 0.106 & $(17.81)$ & $*$ & 0.118 & $(21.27)$ & $*$ & 0.106 & $(24.16)$ & 0.108 & $(25.44)$ & ** \\
\hline Whether a household belongs to ST (Scheduled Tribe) & 0.035 & $(7.97)$ & $*$ & 0.040 & $(9.36)$ & $*$ & 0.046 & $(13.35)$ & 0.050 & $(14.17)$ & * \\
\hline$\theta$ & -0.595 & $(-5.81)$ & $*$ & -0.115 & $(-3.39$ & * & 0.275 & $(9.00)$ & -0.144 & $(-5.61)$ & $*$ \\
\hline$\beta_{\lambda}$ & -0.261 & $(-5.65)$ & * & 0.100 & $(5.20)$ & $*$ & -0.097 & $(-6.52)$ & 0.096 & (6.52) & * \\
\hline Constant & 0.717 & $(7.00)$ & & 0.133 & $(7.42)$ & & 0.229 & $(14.04)$ & 0.295 & $(14.51)$ & \\
\hline Number of obs & & 58664 & & & 58663 & & & 76686 & & 78873 & \\
\hline Wald chi2(103) & Wald chi2(62) & 8662 & & Wald chi2(62) & 15635 & & $\begin{array}{l}\text { Wald } \\
\text { chi2(103) }\end{array}$ & 26299 & & 33759 & \\
\hline Prob > chi2 & & 0 & & & 0 & & & 0 & & 0 & \\
\hline
\end{tabular}




\begin{tabular}{|c|c|c|c|c|c|c|c|c|c|c|c|c|}
\hline \multicolumn{13}{|c|}{ Table 2 continued } \\
\hline \multirow[t]{4}{*}{ 2nd Stage (b) } & Case 1 & & & Case 2 & & & Case 1 & & & & & \\
\hline & NSS50 & & & NSS50 & & & NSS61 & & & & & \\
\hline & RPW & & & PDS & & & RPW & & & PDS & & \\
\hline & Coef. & z & & Coef. & Z & & Coef. & z & & Coef. & $z$ & \\
\hline & \multicolumn{2}{|c|}{ Vulnerability } & & \multicolumn{2}{|c|}{ Vulnerability } & & \multicolumn{2}{|c|}{ Vulnerability } & & \multicolumn{2}{|c|}{ Vulnerability } & \\
\hline Whether a household is headed by a female member & -0.126 & $(-28.69)$ & $*$ & 0.034 & $(1.40)$ & & -0.002 & $(-0.86)$ & & -0.003 & $(-1.51)$ & \\
\hline Number of adult female members & 0.147 & $(106.54)$ & $*$ & 0.056 & (6.91) & $*$ & 0.050 & $(49.97)$ & $*$ & 0.048 & $(46.05)$ & ** \\
\hline Number of adult male members & 0.119 & $(86.24)$ & $*$ & 0.009 & $(1.16)$ & & 0.040 & $(41.87)$ & $*$ & 0.040 & $(42.45)$ & * \\
\hline The proportion of adults in a household & -1.418 & $(-276.53)$ & $*$ & -0.192 & $(-6.37)$ & $*$ & -0.221 & $(-69.10)$ & $*$ & -0.212 & $(-61.86)$ & * \\
\hline Age of household head & 1.096 & $(24.45)$ & $*$ & 1.755 & $(6.42)$ & $*$ & -0.100 & $(-3.10)$ & $*$ & -0.172 & $(-5.07)$ & * \\
\hline Age squared & -1.014 & $(-21.83)$ & $*$ & -1.606 & $(-5.67)$ & $*$ & -0.041 & $(-1.28)$ & & 0.023 & $(0.69)$ & \\
\hline The max. education of adult (Primary) & -0.072 & $(-20.11)$ & $*$ & -0.022 & $(-1.10)$ & & -0.084 & $(-38.86)$ & $*$ & -0.085 & $(-40.57)$ & * \\
\hline The max. education of adult (Middle) & -0.142 & $(-36.66)$ & $*$ & -0.046 & $(-2.06)$ & * & -0.130 & $(-63.92)$ & $*$ & -0.131 & $(-66.07)$ & * \\
\hline The max. education of adult (>=Matriculates) & -0.275 & $(-71.46)$ & $*$ & -0.112 & $(-4.90)$ & $*$ & -0.134 & $(-55.45)$ & $*$ & -0.134 & $(-54.23)$ & * \\
\hline Land $(0.1<=2.5$ ha) (default: the landless) & -0.074 & $(-23.67)$ & $*$ & -0.158 & $(-8.56)$ & $*$ & -0.030 & $(-17.76)$ & $*$ & -0.031 & $(-17.24)$ & * \\
\hline Land (>2.5 ha) (default: the landless) & -0.285 & $(-10.35)$ & $*$ & -0.308 & $(-1.89)$ & + & -0.066 & $(-22.55)$ & $*$ & -0.065 & $(-22.75)$ & ** \\
\hline Whether self-employed in non-agriculture & 0.027 & $(5.96)$ & $*$ & 0.070 & $(2.74)$ & $*$ & 0.007 & $(3.17)$ & $*$ & 0.006 & $(2.38)$ & . \\
\hline Whether agricultural labour & 0.128 & $(31.06)$ & $*$ & 0.102 & $(4.48)$ & $*$ & 0.191 & $(69.90)$ & $*$ & 0.192 & $(66.01)$ & * \\
\hline Whether non-agricultural labour & 0.093 & (15.98) & $*$ & 0.200 & $(6.77)$ & $*$ & 0.072 & $(24.26)$ & $*$ & 0.077 & $(26.48)$ & * \\
\hline Whether self-employed in agriculture & 0.030 & $(7.63)$ & $*$ & -0.067 & $(-2.99)$ & * & 0.011 & $(4.78)$ & $*$ & 0.012 & $(5.30)$ & ** \\
\hline Whether a household belongs to SC (Scheduled Caste) & 0.099 & $(24.16)$ & $*$ & 0.098 & $(4.50)$ & $*$ & 0.121 & $(50.76)$ & ** & 0.123 & $(54.43)$ & * \\
\hline Whether a household belongs to ST (Scheduled Tribe) & 0.062 & $(20.39)$ & $*$ & 0.025 & $(1.41)$ & & 0.052 & $(27.33)$ & $*$ & 0.051 & $(27.40)$ & * \\
\hline$\theta$ & 0.157 & $(1.93)$ & + & -0.014 & $(-2.68)$ & $*$ & 0.223 & (14.19) & $*$ & 0.047 & $(3.44)$ & * \\
\hline$\beta_{\lambda}$ & -0.071 & $(-1.94)$ & $*$ & -0.058 & $(-4.24)$ & * & -0.107 & $(-14.02)$ & $*$ & -0.034 & $(-4.27)$ & * \\
\hline Constant & 0.405 & $(4.98)$ & & -0.716 & -1.42 & & 0.139 & $(15.68)$ & & 0.119 & $(10.96)$ & \\
\hline Number of obs & & 58664 & & & 58663 & & & 76687 & & & 78874 & \\
\hline Wald chi2(103) & & 131349 & & & 137687 & & & 65896.43 & & & 75524.38 & \\
\hline Prob > chi2 & & 0 & & & 0 & & & 0 & & & 0 & \\
\hline
\end{tabular}

${ }^{* *}=$ significant at $1 \%$ level. ${ }^{*}=$ significant at $5 \%$ level. $+=$ significant at $10 \%$ level. 
Table 2 Continued

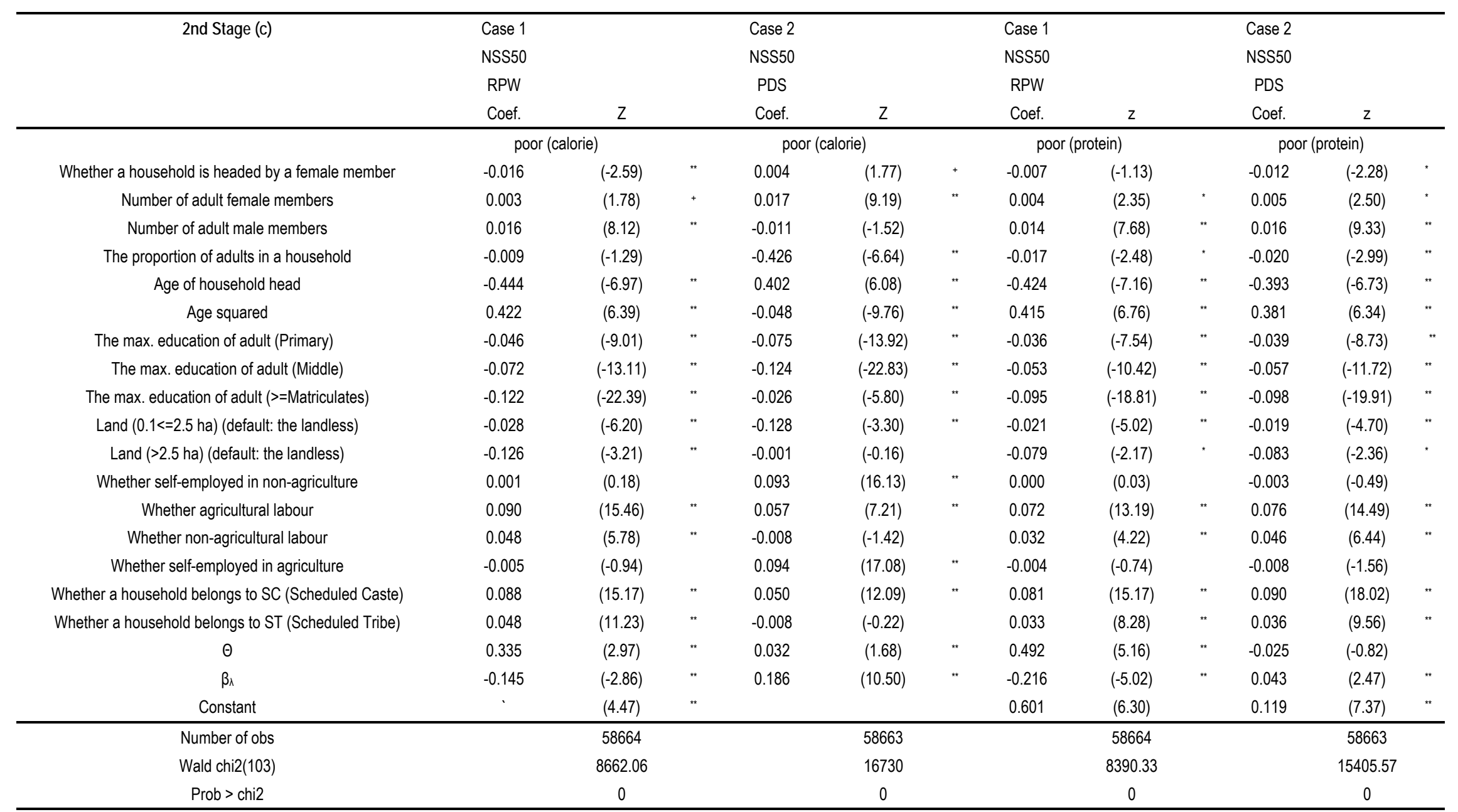

${ }^{* *}=$ significant at $1 \%$ level. ${ }^{*}=$ significant at $5 \%$ level. $+=$ significant at $10 \%$ level. 
Table 3 Treatment Effects Model (Summary of the Final Results)

\section{Policy Effects on Poverty and Undemutrition}

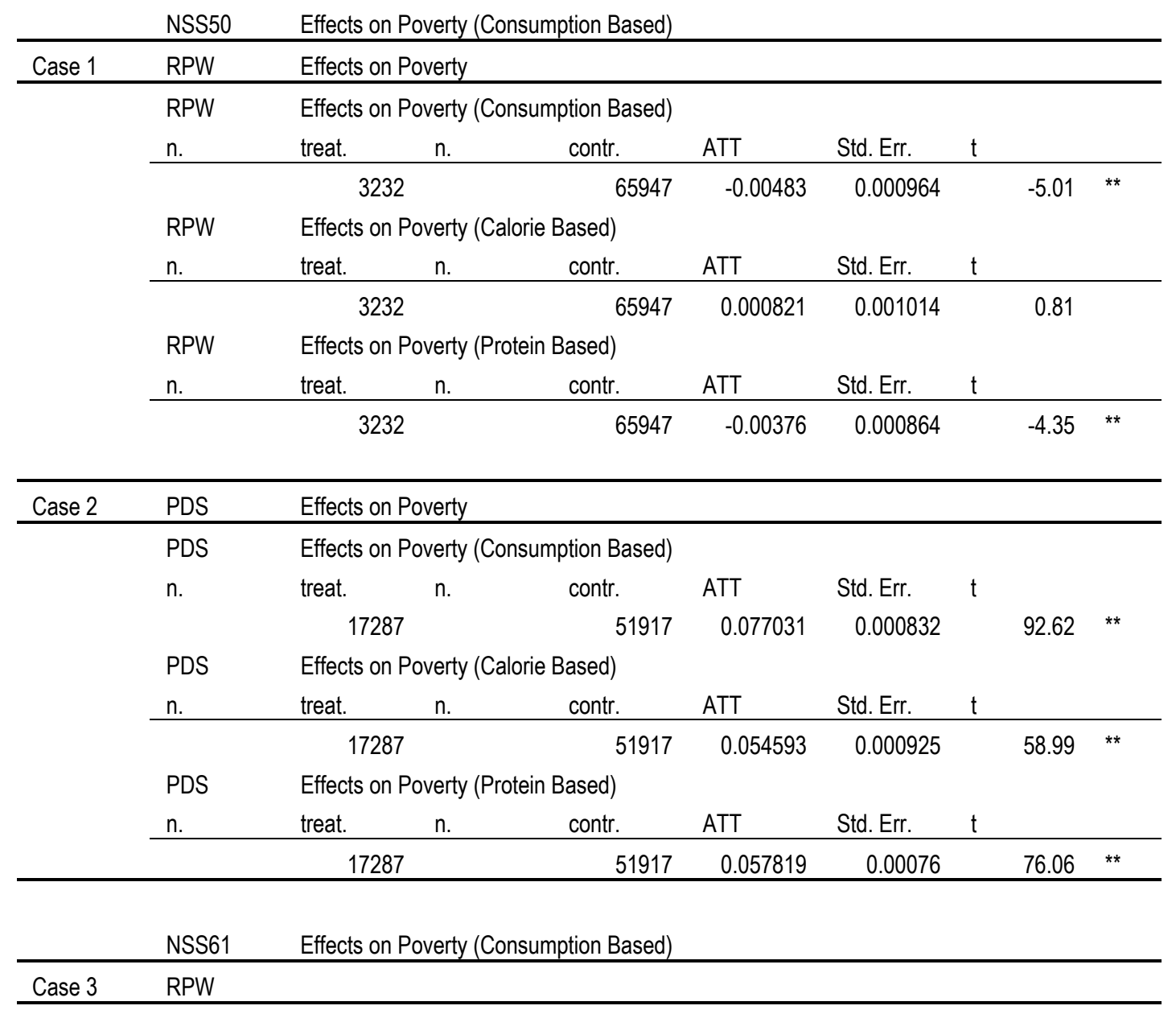

\begin{tabular}{|c|c|c|c|c|c|c|c|c|}
\hline & $\mathrm{n}$. & treat. & $\mathrm{n}$. & contr. & ATT & Std. Err. & $t$ & \\
\hline & \multicolumn{3}{|c|}{2,290} & 76,709 & -0.01565 & 0.001071 & -14.61 & ** \\
\hline Case 4 & PDS & & & & & & & \\
\hline
\end{tabular}

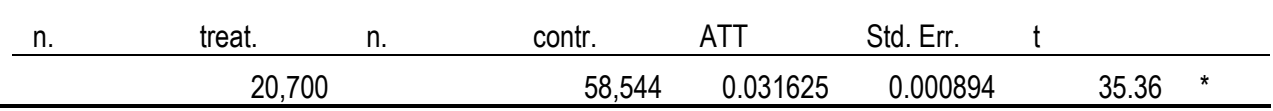




\section{Policy Effects on Vulnerability}

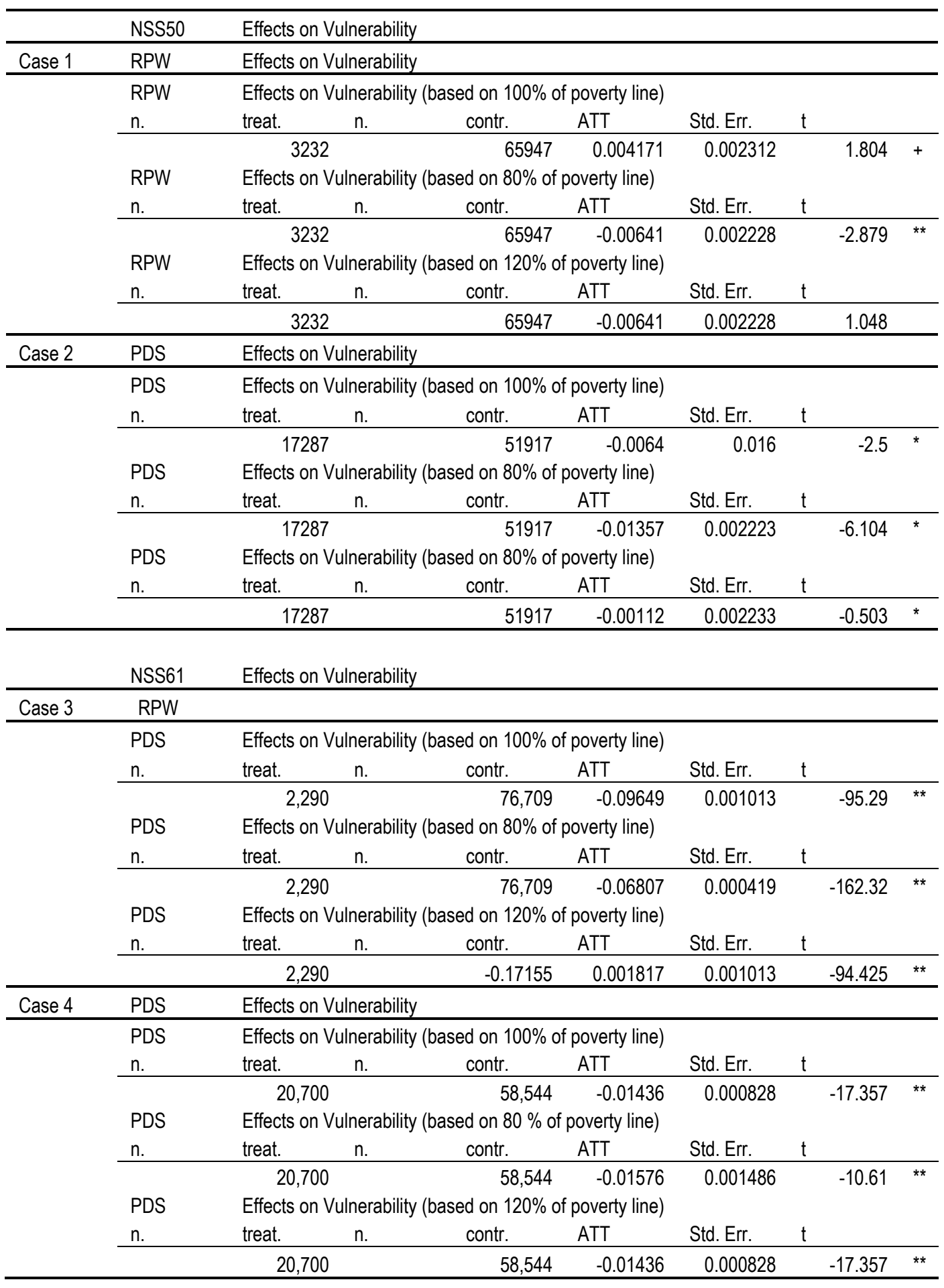


Table 4 Summary of the Results of Propensity Score Matching Models

\section{Probit Models}

\begin{tabular}{|c|c|c|c|c|c|c|c|c|c|c|c|c|}
\hline & NSS50 & & & & & & NSS61 & & & & & \\
\hline & Case 1 & & & Case 2 & & & Case 3 & & & Case 4 & & \\
\hline & RPW & & & PDS & & & RPW & & & PDS & & \\
\hline RPW & Coef. & z & & Coef. & z & & Coef. & z & & Coef. & z & \\
\hline $\begin{array}{l}\text { Number of adult } \\
\text { male members }\end{array}$ & 0.047 & (5.92) & ** & -0.039 & $(-7.27)$ & ** & 0.036 & (3.23) & ** & 0.035 & $(6.06)$ & ** \\
\hline $\begin{array}{c}\text { The proportion of } \\
\text { adults in a } \\
\text { household }\end{array}$ & -0.015 & $(-0.41)$ & & 0.138 & (5.67) & ** & -0.063 & $(-1.50)$ & & -0.242 & $(-11.22)$ & ** \\
\hline $\begin{array}{c}\text { Age of household } \\
\text { head }\end{array}$ & -0.273 & $(-4.08)$ & ** & 0.233 & (5.39) & $\star \star$ & -0.416 & $(-5.81)$ & ** & 0.557 & (15.13) & ** \\
\hline land_pc & -0.040 & $(-2.46)$ & ** & -0.272 & $(-21.55)$ & ** & 0.000 & $(0.56)$ & & -0.001 & $(-1.01)$ & \\
\hline $\begin{array}{l}\text { Predicted } \\
\text { agricultural wage } \\
\text { rate for males }\end{array}$ & 0.002 & $(4.70)$ & ** & - & & & -0.004 & $(-7.27)$ & ** & - & & \\
\hline Food Price Index & - & & & 0.058 & $(68.45)$ & ** & - & & & 0.025 & $(10.26)$ & ** \\
\hline Constant & -1.744 & $(-42.62)$ & & -6.605 & $(-75.60)$ & & -1.448 & $(-28.43)$ & & 0.234 & (7.88) & \\
\hline Number of obs & 69206 & & & 69206 & & & 77043 & & & 79253 & & \\
\hline LR chi2(5) & 69.39 & & & 69.39 & & & 106.07 & & & 530.91 & & \\
\hline Prob > chi2 & 0 & & & 0 & & & 0 & & & 0 & & \\
\hline Pseudo R2 & 0.0027 & & & 0.0027 & & & 0.0051 & & & 0.0058 & & \\
\hline
\end{tabular}

** =significant at $1 \%$ level. $\quad$ *=significant at $5 \%$ level. +=significant at $10 \%$ level. 
Policy Effects on Poverty and Undernutrition (based on bootstrapped standard errors)

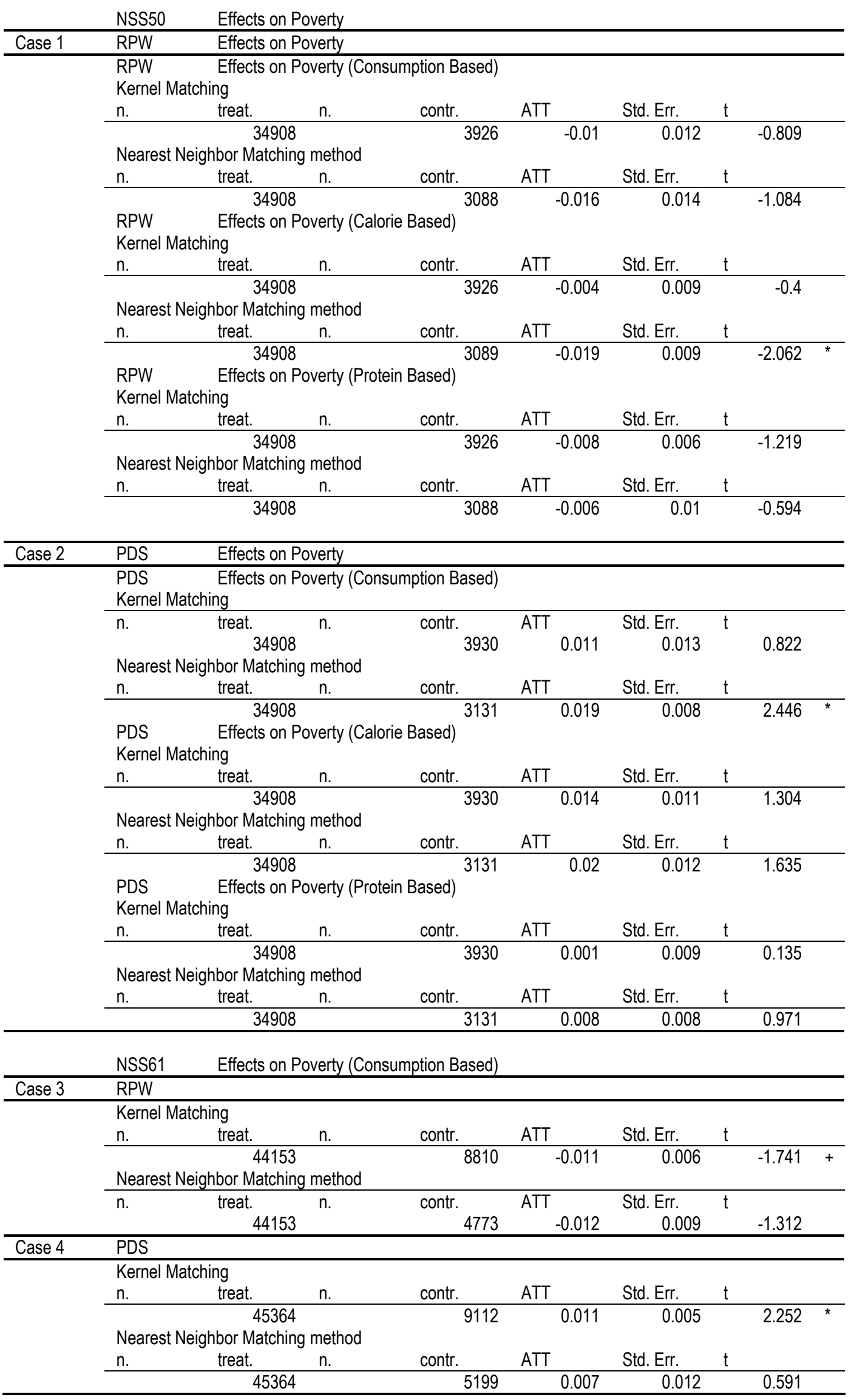


Policy Effects on Vulnerability (based on bootstrapped standard errors)

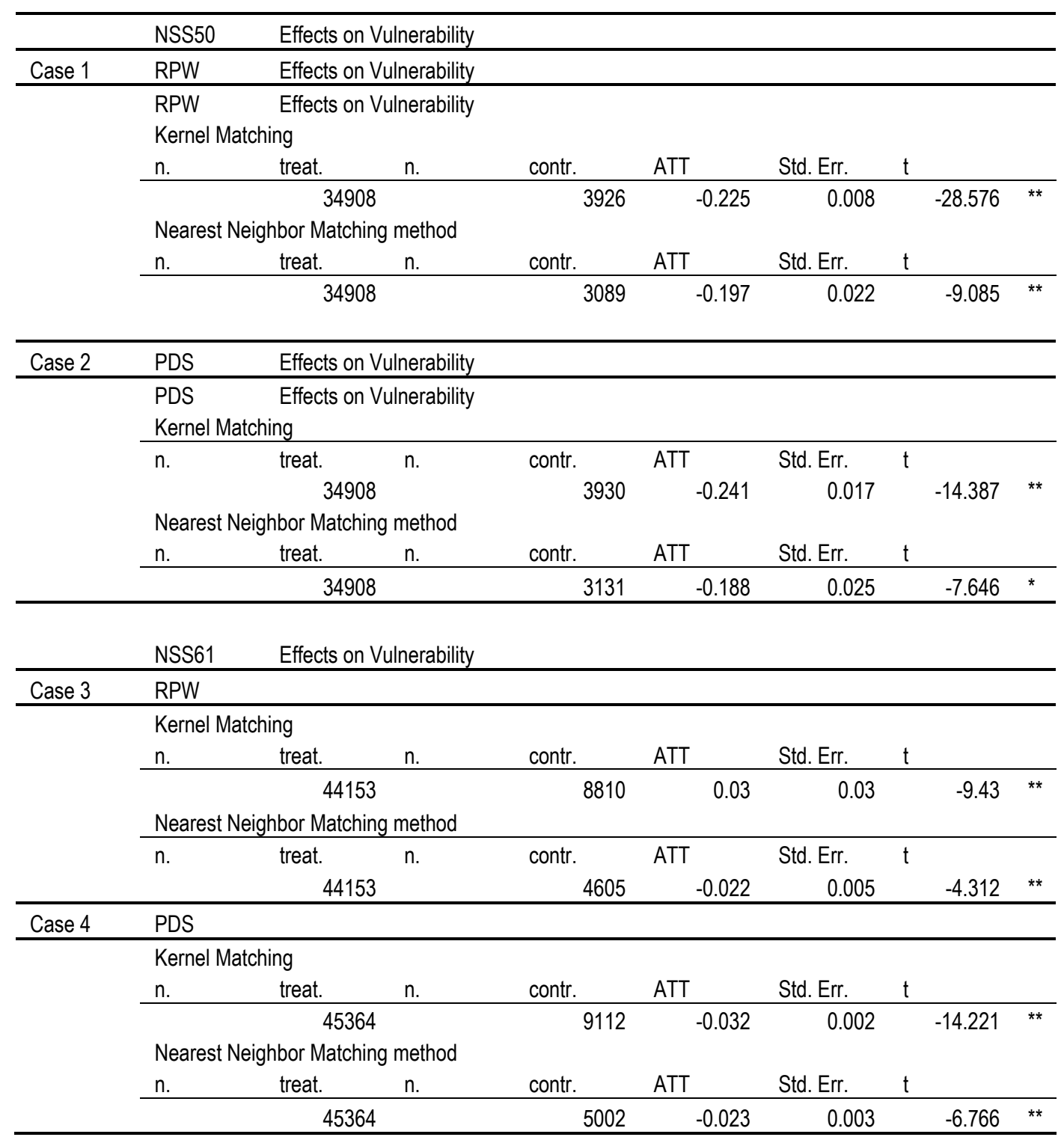


Table 5 Summary of state-wise results of Treatment Effects Models

\begin{tabular}{|c|c|c|c|c|c|c|c|c|c|c|c|c|c|}
\hline & NSS 50 & RPW & & & & & & NSS 50 & PDS & & & & \\
\hline & \multicolumn{7}{|c|}{ Estimated Poverty } & \multicolumn{6}{|c|}{ Estimated Poverty } \\
\hline & A & $B$ & $A-B$ & & & number of & & $A$ & B & $A-B$ & & & number of \\
\hline & With RPW & $\begin{array}{l}\text { Without } \\
\text { RPW }\end{array}$ & ATT & t value & & Observations & & With PDS & Without PDS & ATT & t value & & observations \\
\hline State & & & & & & & State & & & & & & \\
\hline Punjab & 0.096 & 0.054 & 0.042 & 12.34 & ** & 2046 & Punjab & 0.333 & 0.041 & 0.292 & 122.87 & $* *$ & 2046 \\
\hline Haryana & 0.071 & 0.038 & 0.033 & 30.86 & $* *$ & 1040 & Haryana & 0.13 & 0.028 & 0.102 & 21.07 & $* *$ & 1040 \\
\hline Rajasthan & 0.247 & 0.268 & -0.021 & -1129 & * & 3097 & Rajasthan & 0.566 & 0.216 & 0.35 & 194.62 & $* *$ & 3097 \\
\hline Uttar Pradesh & 0.112 & 0.077 & 0.035 & 34.03 & ** & 9010 & Uttar Pradesh & 0.625 & 0.045 & 0.58 & 347.11 & $* *$ & 9010 \\
\hline Bihar & 0.498 & 0.115 & 0.383 & 115.9 & ** & 6976 & Bihar & 0.166 & 0.134 & 0.032 & 17.7 & ** & 6976 \\
\hline Assam & 0.162 & 0.146 & 0.016 & 6.479 & $* *$ & 3199 & Assam & 0.193 & 0.128 & 0.065 & 26.52 & $* *$ & 3199 \\
\hline West Bengal & 0.206 & 0.139 & 0.067 & 38.11 & $* *$ & 5581 & West Bengal & 0.207 & 0.126 & 0.081 & 47.95 & $*$ & 5581 \\
\hline Orissa & 0.18 & 0.213 & -0.033 & -9.779 & $* *$ & 3330 & Orissa & 0.293 & 0.212 & 0.081 & 27.22 & $*$ & 3330 \\
\hline $\begin{array}{l}\text { Madhya } \\
\text { Pradesh }\end{array}$ & 0.139 & 0.182 & -0.043 & -19.074 & ** & 5331 & Madhya Pradesh & 0.214 & 0.172 & 0.042 & 14.5 & $* *$ & 5331 \\
\hline Gujrat & 0.408 & 0.299 & 0.109 & 26.02 & $*$ & 2219 & Gujrat & 0.327 & 0.287 & 0.04 & 11.4 & ** & 2219 \\
\hline Maharastra & 0.45 & 0.448 & 0.002 & 0.594 & & 4440 & Maharastra & 0.499 & 0.423 & 0.076 & 24.38 & $* *$ & 4440 \\
\hline Andhra Pardesh & 0.167 & 0.162 & 0.005 & 2.445 & * & 4908 & Andhra Pardesh & 0.148 & 0.174 & -0.026 & -17.28 & * & 4908 \\
\hline Karnataka & 0.502 & 0.502 & 0.0003 & 0.053 & & 2617 & Karnataka & 0.551 & 0.4495 & 0.1015 & 20.4 & $*$ & 2617 \\
\hline Kerala & 0.35 & 0.277 & 0.073 & 16.54 & $*$ & 2553 & Kerala & 0.27 & 0.298 & -0.028 & -6.208 & * & 2553 \\
\hline Tamil Nadu & 0.172 & 0.231 & -0.059 & -2112 & * & 3901 & Tamil Nadu & 0.187 & 0.229 & -0.042 & -5.542 & * & 3901 \\
\hline All India & 0.157 & 0.162 & -0.005 & -5.01 & ** & 69206 & All India & 0.227 & 0.15 & 0.077 & 92.63 & $* *$ & 69206 \\
\hline
\end{tabular}


Table 5 continued

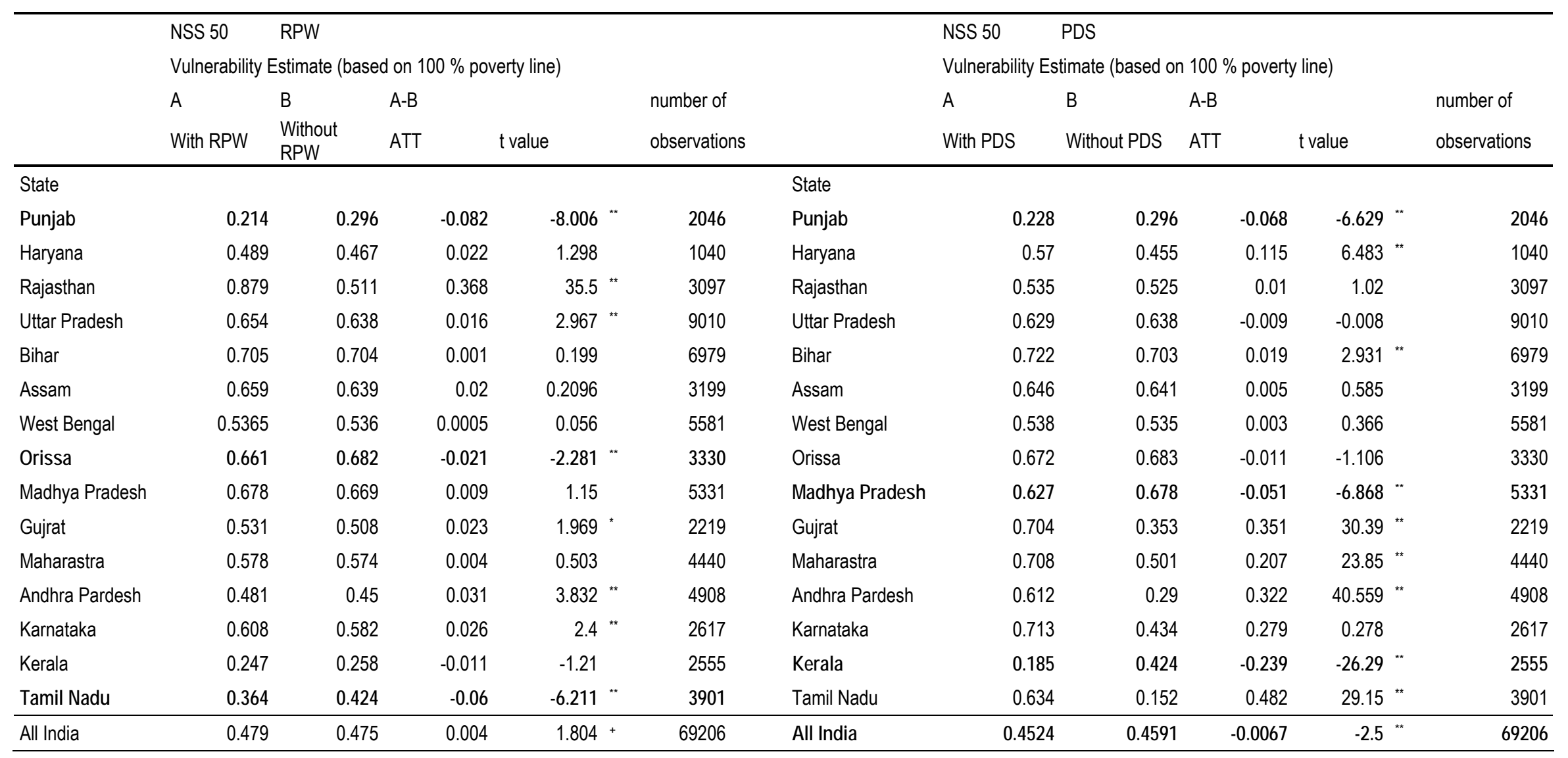


Table 5 continued

\begin{tabular}{|c|c|c|c|c|c|c|c|c|c|c|c|c|c|}
\hline & NSS 61 & RPW & & & & & & NSS 61 & PDS & & & & \\
\hline & \multicolumn{7}{|c|}{ Estimated Poverty } & \multicolumn{6}{|c|}{ Estimated Poverty } \\
\hline & A & B & $A-B$ & & & number of & & A & B & $A-B$ & & & number of \\
\hline & With FFW & $\begin{array}{l}\text { Without } \\
\text { FFW }\end{array}$ & ATT & $\mathrm{t}$ value & & observations & & With PDS & Without PDS & ATT & t value & & observations \\
\hline State & & & & & & & State & & & & & & \\
\hline Punjab & -3.73 & 0.03 & -3.76 & -5.25 & * & 2444 & Punjab & 0.006 & 0.031 & -0.025 & -18.39 & $*$ & 2431 \\
\hline Haryana & -0.293 & 0.052 & -0.345 & -50.84 & * & 1680 & Haryana & 0.066 & 0.039 & 0.027 & 12.71 & $*$ & 1680 \\
\hline Rajasthan & 0.101 & 0.104 & -0.003 & -1.169 & & 3536 & Rajasthan & 0.115 & 0.089 & 0.026 & 10.59 & $*$ & 3536 \\
\hline Uttar Pradesh & 0.99 & 0.234 & 0.756 & 99.12 & ** & 7787 & Uttar Pradesh & 0.243 & 0.185 & 0.058 & 22.6 & $*$ & 7810 \\
\hline Bihar & 0.826 & 0.321 & 0.505 & 63.82 & $* *$ & 4283 & Bihar & 0.323 & 0.309 & 0.014 & 2.667 & $*$ & 4319 \\
\hline Assam & 0.766 & 0.111 & 0.655 & 96.23 & $*$ & 3317 & Assam & 0.118 & 0.095 & 0.023 & 7.754 & $*$ & 3324 \\
\hline West Bengal & 0.132 & 0.16 & -0.028 & -9.97 & * & 4962 & West Bengal & 0.159 & 0.18 & -0.021 & -7.523 & ** & 4967 \\
\hline Orissa & 0.703 & 0.453 & 0.25 & 49.37 & $* *$ & 3800 & Orissa & 0.479 & 0.406 & 0.073 & 12.51 & ** & 3805 \\
\hline $\begin{array}{l}\text { Madhya } \\
\text { Pradesh }\end{array}$ & 0.337 & 0.332 & 0.005 & 1.11 & & 3832 & Madhya Pradesh & 0.236 & 0.505 & -0.269 & -5156 & $*$ & 3833 \\
\hline Gujrat & 0.768 & 0.09 & 0.678 & 47.87 & $*$ & 2302 & Gujrat & 0.12 & 0.082 & 0.038 & 11.25 & $*$ & 2302 \\
\hline Maharastra & 0.093 & 0.202 & -0.109 & -3275 & $*$ & 5000 & Maharastra & 0.196 & 0.193 & 0.003 & 0.812 & & 5000 \\
\hline $\begin{array}{l}\text { Andhra } \\
\text { Pardesh }\end{array}$ & 0.118 & 0.174 & -0.056 & -16.09 & * & 5500 & Andhra Pardesh & 0.185 & 0.129 & 0.056 & 23.23 & $* *$ & 5500 \\
\hline Karnataka & 0.639 & 0.199 & 0.44 & 23.11 & $*$ & 2880 & Karnataka & 0.218 & 0.138 & 0.08 & 19.75 & $*$ & 2880 \\
\hline Kerala & 0.679 & 0.044 & 0.635 & 10.82 & $* *$ & 3292 & Kerala & 0.44 & 0.036 & 0.404 & 7.09 & $*$ & 3292 \\
\hline Tamil Nadu & 0.719 & 0.169 & 0.55 & 44.43 & $*$ & 4137 & Tamil Nadu & 0.171 & 0.087 & 0.084 & 28.99 & $*$ & 4137 \\
\hline All India & 0.164 & 0.179 & -0.015 & -14.61 & ** & 76687 & All India & 0.186 & 0.154 & 0.032 & 35.37 & $* *$ & 78874 \\
\hline
\end{tabular}


Table 5 Continued

\begin{tabular}{|c|c|c|c|c|c|c|c|c|c|c|c|c|c|}
\hline & NSS 61 & RPW & & & & & & NSS 61 & PDS & & & & \\
\hline & \multicolumn{7}{|c|}{ Vulnerability Estimate (based on $100 \%$ poverty line) } & \multicolumn{6}{|c|}{ Vulnerability Estimate (based on $100 \%$ poverty line) } \\
\hline & A & $\begin{array}{l}\text { B } \\
\text { Without }\end{array}$ & $A-B$ & & & number of & & A & B & $A-B$ & & & number of \\
\hline & With FFW & FFW & ATT & t value & & observations & & With PDS & Without PDS & ATT & t value & & Observations \\
\hline State & & & & & & & State & & & & & & \\
\hline Punjab & 9.05 & 0.003 & 9.047 & 5.455 & ** & 2444 & Punjab & 0.00015 & 0.0004 & -0.00025 & -2.607 & $*$ & 2431 \\
\hline Haryana & 0.0008 & 0.001 & -0.0002 & 18.98 & ** & 1680 & Haryana & 0.0147 & -0.008 & 0.0227 & 84.57 & $* *$ & 1680 \\
\hline Rajasthan & 0.127 & 0.001 & 0.126 & 97.18 & ** & 3536 & Rajasthan & 0.0172 & 0.0195 & -0.0023 & -2.02 & * & 3536 \\
\hline Uttar Pradesh & 2.708 & 0.053 & 2.655 & 406.66 & $* *$ & 7787 & Uttar Pradesh & 0.0609 & 0.0622 & -0.0013 & -0.638 & & 7810 \\
\hline Bihar & 0.142 & 0.225 & -0.083 & -7.436 & * & 4283 & Bihar & 0.224 & 0.226 & -0.002 & -0.192 & & 4319 \\
\hline Assam & 0.027 & 0.016 & 0.011 & 8.39 & ** & 3317 & Assam & 0.014 & 0.024 & -0.01 & -10.75 & $* *$ & 3324 \\
\hline West Bengal & 0.023 & 0.035 & -0.012 & -6.78 & ** & 4962 & West Bengal & 0.031 & 0.065 & -0.034 & -19.34 & $*$ & 4967 \\
\hline $\begin{array}{l}\text { Orissa } \\
\text { Madhya }\end{array}$ & 0.432 & 0.41 & 0.022 & 2.433 & * & 3800 & Orissa & 0.375 & 0.531 & -0.156 & -17.4 & $*$ & 3805 \\
\hline Pradesh & 1.591 & 0.209 & 1.382 & 174.96 & ** & 3832 & Madhya Pradesh & 0.147 & 0.377 & -0.23 & -31.48 & $*$ & 3833 \\
\hline Gujrat & 0.25 & 0.0009 & 0.2491 & 47.22 & ** & 2302 & Gujrat & 0.012 & 0.032 & -0.02 & -15.01 & ** & 2302 \\
\hline Maharastra & 0.0945 & 0.0675 & 0.027 & 9.547 & ** & 5000 & Maharastra & 0.067 & 0.067 & 0.0004 & 0.158 & & 5000 \\
\hline Andhra Pardesh & 0.312 & 0.009 & 0.303 & 226.28 & ** & 5500 & Andhra Pardesh & -0.033 & 0.138 & -0.171 & -14 & $* *$ & 5501 \\
\hline Karnataka & 2.033 & 0.098 & 1.935 & 136.05 & ** & 2880 & Karnataka & 0.085 & 0.147 & -0.062 & -1231 & $*$ & 2880 \\
\hline Kerala & -0.0003 & 0.0004 & -0.0007 & -9.803 & * & 3292 & Kerala & -0.002 & 0.005 & -0.007 & -66.08 & $*$ & 3292 \\
\hline Tamil Nadu & 0.076 & 0.025 & 0.051 & 13.7 & ** & 4137 & Tamil Nadu & 0.024 & 0.019 & 0.005 & 3.33 & $*$ & 4137 \\
\hline All India & -0.015 & 0.082 & -0.097 & -95.29 & * & 76687 & All India & 0.077 & 0.091 & -0.014 & -17.36 & * & 78874 \\
\hline
\end{tabular}

${ }^{* *}=$ significant at $1 \%$ level. ${ }^{*}=$ significant at $5 \%$ level. $+=$ significant at $10 \%$ level. 
Table 6 Pseudo Panel Model

\begin{tabular}{|c|c|c|c|c|c|c|c|c|c|c|c|c|}
\hline \multicolumn{13}{|l|}{ G2SLS random-effects IV regression } \\
\hline & 1st Stage & RPW & & 1st Stage & PDS & & 1st Stage & RPW & & 1st Stage & PDS & \\
\hline & Coef. & z & & Coef. & z & & Coef. & z & & Coef. & z & \\
\hline Whether a household is headed by a female member & -0.088 & $(-0.49)$ & & 0.705 & $(1.37)$ & & 0.095 & $(0.54)$ & & -0.404 & $(-0.64)$ & \\
\hline Number of adult female members & 0.042 & $(0.52)$ & & 0.296 & $(1.14)$ & & 0.014 & $(0.19)$ & & 0.734 & $(2.88)$ & ** \\
\hline Number of adult male members & -0.074 & $(-1.00)$ & & -0.453 & $(-2.12)$ & * & -0.013 & $(-0.20)$ & & -0.748 & $(-3.31)$ & ** \\
\hline The proportion of adults in a household & 0.104 & $(0.59)$ & & 0.020 & $(0.04)$ & & 0.139 & $(0.97)$ & & -0.019 & $(-0.03)$ & \\
\hline Age of household head & -1.496 & $(-0.65)$ & & 9.725 & $(1.43)$ & & -1.153 & $(-0.50)$ & & 3.892 & $(0.48)$ & \\
\hline Age squared & 1.168 & $(0.51)$ & & -9.895 & $(-1.40)$ & & 0.622 & $(0.27)$ & & -3.359 & $(-0.41)$ & \\
\hline The max. education of adult (Primary) & 0.069 & $(0.87)$ & & 0.532 & $(2.00)$ & & 0.077 & $(1.25)$ & & 0.192 & $(0.86)$ & \\
\hline The max. education of adult (Middle) & 0.039 & $(0.44)$ & & 0.724 & $(2.59)$ & * & 0.038 & $(0.52)$ & & 0.965 & $(3.68)$ & ** \\
\hline The max. education of adult (>=Matriculates) & 0.010 & $(0.08)$ & & 0.174 & $(0.47)$ & & 0.001 & $(0.01)$ & & 0.192 & $(0.50)$ & \\
\hline Land ( $0.1<=2.5$ ha) (default: the landless) & 0.039 & $(0.98)$ & & 0.157 & $(1.16)$ & & -0.009 & $(-0.30)$ & & 0.061 & $(0.62)$ & \\
\hline Land (>2.5 ha) (default: the landless) & 0.100 & (1.95) & + & 0.517 & $(3.15)$ & $* *$ & 0.066 & $(1.73)$ & + & 0.623 & $(4.39)$ & ** \\
\hline Whether self-employed in non-agriculture & -0.173 & $(-1.39)$ & & 0.420 & $(1.10)$ & & -0.177 & $(-1.56)$ & & -0.076 & $(-0.19)$ & \\
\hline Whether agricultural labour & -0.083 & $(-0.78)$ & & 0.645 & $(2.36)$ & * & 0.047 & $(0.49)$ & & 0.216 & $(0.68)$ & \\
\hline Whether non-agricultural labour & 0.006 & $(0.07)$ & & 0.494 & $(1.64)$ & & 0.003 & $(0.03)$ & & 0.121 & $(0.31)$ & \\
\hline Whether self-employed in agriculture & -0.027 & $(-0.29)$ & & 0.309 & $(1.08)$ & & 0.067 & $(0.79)$ & & -0.094 & $(-0.29)$ & \\
\hline Whether a household belongs to SC (Scheduled Caste) & 0.011 & $(0.95)$ & & -0.050 & $(-1.34)$ & & 0.007 & $(0.67)$ & & -0.029 & $(-0.76)$ & \\
\hline Whether a household belongs to ST (Scheduled Tribe) & 0.009 & $(0.67)$ & & -0.032 & $(-0.68)$ & & 0.008 & $(0.63)$ & & 0.019 & $(0.42)$ & \\
\hline Predicted agricultural wage rate for males & 0.000 & $(-0.63)$ & & - & - & & 0.000 & $(0.22)$ & & - & - & \\
\hline Food Price Index & - & - & & 0.010 & $(2.60)$ & * & 0.000 & $(0.22)$ & & 0.010 & $(2.80)$ & ** \\
\hline Whether in 1993 & 0.057 & $(0.94)$ & & -0.923 & $(-2.07)$ & * & 0.060 & $(1.06)$ & & -0.888 & $(-2.17)$ & * \\
\hline Constant & 0.422 & $(0.84)$ & & -2.426 & $(-1.75)$ & & 0.277 & $(0.55)$ & & -0.939 & $(-0.55)$ & \\
\hline
\end{tabular}




\begin{tabular}{|c|c|c|c|c|c|c|c|c|c|c|c|}
\hline \multirow[t]{2}{*}{ 2nd stage } & \multirow{2}{*}{$\begin{array}{c}\text { Poverty } \\
\text { Coef. }\end{array}$} & \multicolumn{4}{|c|}{ Poverty } & & \multicolumn{2}{|c|}{ Vulnerability (100\%) } & \multicolumn{3}{|c|}{ Vulnerability $(100 \%)$} \\
\hline & & Z & & Coef. & z & & Coef. & Z & Coef. & Z & \\
\hline RPW & 0.038 & $(0.01)$ & & & & & -8.477 & $(-0.21)$ & - & & \\
\hline PDS & - & - & & 0.351 & (1.25) & & - & & -0.262 & $(-1.34)$ & \\
\hline Whether a household is headed by a female member & -0.293 & $(-0.46)$ & & -0.410 & $(-0.97)$ & ** & 1.170 & $(0.28)$ & -0.297 & $(-0.83)$ & \\
\hline Number of adult female members & 0.238 & $(0.87)$ & & 0.119 & $(0.55)$ & & 0.127 & $(0.14)$ & 0.118 & $(0.61)$ & \\
\hline Number of adult male members & -0.180 & $(-0.48)$ & & -0.024 & $(-0.12)$ & ** & 0.258 & $(0.33)$ & 0.006 & $(0.03)$ & \\
\hline The proportion of adults in a household & -0.717 & $(-1.19)$ & & -0.742 & $(-1.85)$ & ** & 1.038 & $(0.18)$ & -0.705 & $(-2.19)$ & * \\
\hline Age of household head & 1.715 & $(0.21)$ & & -3.752 & $(-0.58)$ & ** & -16.422 & $(-0.32)$ & 1.372 & $(0.30)$ & \\
\hline Age squared & -1.242 & $(-0.17)$ & & 4.148 & $(0.62)$ & & 11.429 & $(0.34)$ & -0.283 & $(-0.06)$ & \\
\hline The max. education of adult (Primary) & 0.450 & $(1.32)$ & & 0.275 & $(0.97)$ & & 0.487 & $(0.16)$ & 0.188 & $(1.36)$ & \\
\hline The max. education of adult (Middle) & 0.195 & $(0.68)$ & & -0.040 & $(-0.14)$ & ** & -0.018 & $(-0.01)$ & 0.045 & $(0.20)$ & \\
\hline The max. education of adult (>==Matriculates) & -0.444 & $(-1.38)$ & & -0.398 & $(-1.39)$ & ** & -0.765 & $(-0.89)$ & -0.265 & $(-1.24)$ & \\
\hline Land (0.1<=2.5 ha) (default: the landless) & 0.189 & $(1.00)$ & & 0.105 & $(0.91)$ & & -0.062 & $(-0.14)$ & 0.110 & $(1.89)$ & + \\
\hline Land (>2.5 ha) (default: the landless) & 0.231 & $(0.53)$ & & 0.039 & $(0.20)$ & & 0.369 & $(0.14)$ & 0.055 & $(0.35)$ & \\
\hline Whether self-employed in non-agriculture & -0.657 & $(-0.95)$ & & -0.596 & $(-2.23)$ & ** & -1.885 & $(-0.25)$ & -0.291 & $(-1.33)$ & \\
\hline Whether agricultural labour & 0.010 & $(0.03)$ & & 0.019 & $(0.09)$ & + & 0.444 & $(0.24)$ & 0.037 & $(0.23)$ & \\
\hline Whether non-agricultural labour & -0.438 & $(-1.72)$ & + & -0.508 & $(-2.08)$ & $* *$ & 0.139 & $(0.15)$ & 0.146 & $(0.70)$ & \\
\hline Whether self-employed in agriculture & -0.653 & $(-2.71)$ & ** & -0.482 & $(-2.60)$ & ** & 0.462 & $(0.17)$ & -0.216 & $(-1.14)$ & \\
\hline Whether a household belongs to SC (Scheduled Caste) & 0.014 & $(0.26)$ & & 0.041 & $(1.28)$ & & 0.102 & $(0.34)$ & 0.025 & $(1.14)$ & \\
\hline Whether a household belongs to ST (Scheduled Tribe) & -0.007 & $(-0.14)$ & & 0.009 & $(0.24)$ & & 0.097 & $(0.28)$ & 0.019 & $(0.78)$ & \\
\hline Whether in 1993 & 0.159 & $(0.56)$ & & 1.402184 & $(0.24)$ & & 0.17 & $(0.01)$ & 0.4 & $(3.66)$ & ** \\
\hline Constant & 0.281 & $(0.13)$ & & 0.158 & $(1.16)$ & & 4.196 & $(0.34)$ & 0.036 & $(0.04)$ & \\
\hline Number of obs & & 136 & & & 136 & & & 127 & & 136 & \\
\hline Wald chi(18) & & 83.42 & & & 47 & & & 75 & & 348 & \\
\hline Prob > chi2 & & 0 & & & 0 & & & 0 & & 0 & \\
\hline
\end{tabular}

\begin{tabular}{|c|c|c|c|c|c|c|c|c|}
\hline \multirow[t]{2}{*}{ 2nd stage } & \multirow{2}{*}{$\begin{array}{c}\text { Vulnerability } \\
(80 \%) \\
\text { Coef. }\end{array}$} & \multicolumn{3}{|c|}{$\begin{array}{c}\text { Vulnerability } \\
(\mathbf{8 0 \% )}\end{array}$} & \multicolumn{2}{|c|}{ Vulnerability (120\%) } & \multicolumn{2}{|c|}{ Vulnerability (120\%) } \\
\hline & & z & Coef. & z & Coef. & z & Coef. & z \\
\hline RPW & -0.09 & $(-049)$ & & & 0.19 & (0.32) & - & \\
\hline PDS & - & - & -0.65 & $(-2.44)^{*}$ & - & & 0.05 & $(0.23)$ \\
\hline
\end{tabular}




\section{Appendix 1 Definitions and Descriptive Statistics of the Variables}

\begin{tabular}{|c|c|}
\hline Variable & Definition \\
\hline $\begin{array}{l}\text { Whether a household is headed by a female } \\
\text { member }\end{array}$ & Whether a household is headed by a female member, ( $=1$ if yes, $=0$ if no) \\
\hline Number of adult female members & Number of adult female members ( 15 years old or above) in a household \\
\hline Number of adult male members & Number of adult male members ( 15 years old or above) in a household \\
\hline The proportion of adults in a household & The share of adults ( 15 years- 60 years) in the total number of household members \\
\hline Age of household head & Age of household head (years) \\
\hline Age squared & $\begin{array}{l}\text { Square of age of household head } \\
\text { The maximum level of educational attainment of adult member in the household is the }\end{array}$ \\
\hline The max. education of adult (Primary) & $\begin{array}{l}\text { completion of primary school } \\
\text { The maximum level of educational attainment of adult member in the household is the }\end{array}$ \\
\hline The max. education of adult (Middle) & $\begin{array}{l}\text { completion of middle school } \\
\text { The maximum level of educational attainment of adult member in the household is } \\
\text { matriculates or higher }\end{array}$ \\
\hline Land $(0.1<=2.5$ ha) (default: the landless) & The area of owned land of the household is from 0,1 hectare to 2.5 hectare \\
\hline Land (>2.5 ha) (default: the landless) & The area of owned land of the household is larger than 2.5 hectare \\
\hline Land pc & The area of owned land per capita \\
\hline Whether self-employed in non-agriculture & $\begin{array}{l}(=1 \text { if yes, }=0 \text { if no).- default of the four choices is 'others' } \\
\text { Whether the occupation type of the household head is agricultural labour }\end{array}$ \\
\hline Whether agricultural labour & $\begin{array}{l}\text { (=1 if yes, }=0 \text { if no) } \\
\text { Whether the occupation type of the household head is labour in non-agriculture }\end{array}$ \\
\hline Whether non-agricultural labour & $\begin{array}{l}(=1 \text { if yes, }=0 \text { if no) } \\
\text { Whether the occupation type of the household head is self-employed in agriculture }\end{array}$ \\
\hline $\begin{array}{l}\text { Whether self-employed in agriculture } \\
\text { Whether a household belongs to SC }\end{array}$ & $(=1$ if yes, $=0$ if no) \\
\hline $\begin{array}{l}\text { (Scheduled Caste) } \\
\text { Whether a household belongs to ST }\end{array}$ & Whether a household belongs to SC (Scheduled Caste) (=1 if yes, $=0$ if no) \\
\hline (Scheduled Tribe) & Whether a household belongs to ST (Scheduled Tribe) (=1 if yes, $=0$ if no) \\
\hline PDS & Whether a household has access to Public Distribution System \\
\hline RPW & Whether a household has access to Rural Public Works \\
\hline FFW & Whether a household has access to Food for Work Programme \\
\hline Predicted agricultural wage rate for males & Agricultural Wage Rate for male workers averaged at NSS region \\
\hline Food Price Index & $\begin{array}{l}\text { Food Price Index based on Deaton and Tarozzi }(2000) \\
\text { Whether the household per capita expenditure is under the national poverty line for rural }\end{array}$ \\
\hline Poor & areas \\
\hline poor (calorie based) & Whether the household is undernourished in terms of calorie intakes \\
\hline poor (protein based) & Whether the household is undernourished in terms of protein intakes \\
\hline Vulnerability Measure & \\
\hline $\begin{array}{l}\text { (based on } 100 \% \text { income poverty line) } \\
\text { Vulnerability Measure }\end{array}$ & Whether the household is vulnerable (based on $100 \%$ of the national poverty line) \\
\hline $\begin{array}{l}\text { (based on } 80 \% \text { income poverty line) } \\
\text { Vulnerability Measure }\end{array}$ & Whether the household is vulnerable (based on $80 \%$ of the national poverty line) \\
\hline (based on $120 \%$ income poverty line) & Whether the household is vulnerable (based on $120 \%$ of the national poverty line) \\
\hline
\end{tabular}




\begin{tabular}{|c|c|c|c|c|c|c|c|c|c|c|}
\hline \multirow[b]{2}{*}{ Variable } & \multirow[b]{2}{*}{ Obs } & \multicolumn{3}{|c|}{ Without RPW } & \multirow[b]{2}{*}{ Max } & \multirow[b]{2}{*}{ Obs } & \multicolumn{3}{|c|}{ With RPW } & \multirow[b]{2}{*}{ Max } \\
\hline & & Mean & Std. Dev. & Min & & & Mean & Std. Dev. & Min & \\
\hline $\begin{array}{c}\text { Whether a household is headed } \\
\text { by a female member }\end{array}$ & 65974 & 0.097 & 0.295 & 0 & 1 & 3232 & 0.066 & 0.248 & 0 & 1 \\
\hline $\begin{array}{l}\text { Number of adult female } \\
\text { members }\end{array}$ & 65974 & 1.613 & 0.961 & 0 & 20 & 3232 & 1.611 & 0.948 & 0 & 8 \\
\hline Number of adult male members & 65974 & 1.661 & 1.092 & 0 & 25 & 3232 & 1.750 & 1.094 & 0 & 14 \\
\hline $\begin{array}{c}\text { The proportion of adults in a } \\
\text { household }\end{array}$ & 65974 & 0.683 & 0.234 & 0 & 1 & 3232 & 0.681 & 0.230 & 0 & 1 \\
\hline Age of household head & 65974 & 0.445 & 0.139 & 0 & 0.99 & 3232 & 0.439 & 0.134 & 0 & 0.92 \\
\hline Age squared & 65974 & 0.217 & 0.133 & 0 & 0.9801 & 3232 & 0.211 & 0.126 & 0 & 0.8464 \\
\hline $\begin{array}{l}\text { The max. education of adult } \\
\text { (Primary) }\end{array}$ & 65974 & 0.106 & 0.308 & 0 & 1 & 3232 & 0.078 & 0.268 & 0 & 1 \\
\hline $\begin{array}{l}\text { The max. education of adult } \\
\text { (Middle) }\end{array}$ & 65974 & 0.090 & 0.287 & 0 & 1 & 3232 & 0.066 & 0.249 & 0 & 1 \\
\hline $\begin{array}{l}\text { The max. education of adult } \\
\text { (>=Matriculates) }\end{array}$ & 65974 & 0.250 & 0.433 & 0 & 1 & 3232 & 0.334 & 0.472 & 0 & 1 \\
\hline $\begin{array}{l}\text { Land }(0.1<=2.5 \mathrm{ha}) \\
\text { (default: the landless) }\end{array}$ & 65974 & 0.266 & 0.442 & 0 & 1 & 3232 & 0.231 & 0.422 & 0 & 1 \\
\hline $\begin{array}{c}\text { Land (>2.5 ha) (default: the } \\
\text { landless) }\end{array}$ & 65974 & 0.149 & 0.356 & 0 & 1 & 3232 & 0.258 & 0.438 & 0 & 1 \\
\hline $\begin{array}{c}\text { Whether self-employed in } \\
\text { non-agriculture }\end{array}$ & 65974 & 0.122 & 0.327 & 0 & 1 & 3232 & 0.091 & 0.288 & 0 & 1 \\
\hline Whether agricultural labour & 65974 & 0.240 & 0.427 & 0 & 1 & 3232 & 0.287 & 0.453 & 0 & 1 \\
\hline Whether non-agricultural labour & 65974 & 0.071 & 0.257 & 0 & 1 & 3232 & 0.124 & 0.329 & 0 & 1 \\
\hline $\begin{array}{l}\text { Whether self-employed in } \\
\text { agriculture }\end{array}$ & 65974 & 0.425 & 0.494 & 0 & 1 & 3232 & 0.358 & 0.479 & 0 & 1 \\
\hline $\begin{array}{l}\text { Whether a household belongs to } \\
\text { SC (Scheduled Caste) }\end{array}$ & 65974 & 0.147 & 0.354 & 0 & 1 & 3232 & 0.212 & 0.409 & 0 & 1 \\
\hline $\begin{array}{c}\text { Whether a household belongs to } \\
\text { ST (Scheduled Tribe) }\end{array}$ & 65974 & 0.187 & 0.390 & 0 & 1 & 3232 & 0.213 & 0.409 & 0 & 1 \\
\hline PDS & 65972 & 0.248 & 0.432 & 0 & 1 & 3232 & 0.289 & 0.454 & 0 & 1 \\
\hline RPW & 65974 & 0.000 & 0.000 & 0 & 0 & 3232 & 1.000 & 0.000 & 1 & 1 \\
\hline $\begin{array}{l}\text { Predicted agricultural wage rate } \\
\text { for males }\end{array}$ & 65974 & 65.329 & 20.145 & 29.56 & 141.06 & 3232 & 67.055 & 20.456 & 29.55586 & 141.0612 \\
\hline Food Price Index & 65974 & 100.348 & 6.433 & 91.8 & 116.5 & 3232 & 100.107 & 5.886 & 91.8 & 116.5 \\
\hline Poor & 56263 & 0.199 & 0.399 & 0 & 1 & 2401 & 0.252 & 0.434 & 0 & 1 \\
\hline poor (calorie based) & 56263 & 0.202 & 0.401 & 0 & 1 & 2401 & 0.253 & 0.435 & 0 & 1 \\
\hline poor (protein based) & 56263 & 0.154 & 0.361 & 0 & 1 & 2401 & 0.200 & 0.400 & 0 & 1 \\
\hline $\begin{array}{l}\text { Vulnerability Measure (based on } \\
100 \% \text { income poverty line) }\end{array}$ & 56263 & 0.571 & 0.478 & 0 & 1 & 2401 & 0.632 & 0.467 & 0 & 1 \\
\hline $\begin{array}{l}\text { Vulnerability Measure (based on } \\
80 \% \text { income poverty line) }\end{array}$ & 56263 & 0.432 & 0.476 & 0 & 1 & 2401 & 0.491 & 0.480 & 0 & 1 \\
\hline $\begin{array}{l}\text { Vulnerability Measure (based on } \\
120 \% \text { income poverty line) }\end{array}$ & 56263 & 0.668 & 0.456 & 0 & 1 & 2401 & 0.715 & 0.437 & 0 & 1 \\
\hline
\end{tabular}


NSS 50 Continued

\begin{tabular}{|c|c|c|c|c|c|c|c|c|c|c|}
\hline Without PDS & & & & & & With PDS & & & & \\
\hline Variable & Obs & Mean & Std. Dev. & Min & Max & Obs & Mean & Std. Dev. & Min & Max \\
\hline $\begin{array}{c}\text { Whether a household is headed } \\
\text { by a female member }\end{array}$ & 51917 & 0.086 & 0.281 & 0 & 1 & 17287 & 0.123 & 0.328 & 0 & 1 \\
\hline $\begin{array}{l}\text { Number of adult female } \\
\text { members }\end{array}$ & 51917 & 1.605 & 0.964 & 0 & 16 & 17287 & 1.638 & 0.948 & 0 & 20 \\
\hline Number of adult male members & 51917 & 1.681 & 1.098 & 0 & 14 & 17287 & 1.618 & 1.074 & 0 & 25 \\
\hline $\begin{array}{c}\text { The proportion of adults in a } \\
\text { household }\end{array}$ & 51917 & 0.679 & 0.235 & 0 & 1 & 17287 & 0.694 & 0.232 & 0 & 1 \\
\hline Age of household head & 51917 & 0.443 & 0.141 & 0 & 0.99 & 17287 & 0.449 & 0.133 & 0 & 0.99 \\
\hline Age squared & 51917 & 0.216 & 0.134 & 0 & 0.9801 & 17287 & 0.219 & 0.128 & 0 & 0.9801 \\
\hline $\begin{array}{l}\text { The max. education of adult } \\
\text { (Middle) }\end{array}$ & 51917 & 0.091 & 0.288 & 0 & 1 & 17287 & 0.083 & 0.276 & 0 & 1 \\
\hline $\begin{array}{l}\text { The max. education of adult } \\
\text { (>=Matriculates) }\end{array}$ & 51917 & 0.237 & 0.425 & 0 & 1 & 17287 & 0.303 & 0.459 & 0 & 1 \\
\hline $\begin{array}{c}\text { Land }(0.1<=2.5 \text { ha) (default: the } \\
\text { landless) }\end{array}$ & 51917 & 0.292 & 0.455 & 0 & 1 & 17287 & 0.181 & 0.385 & 0 & 1 \\
\hline $\begin{array}{c}\text { Land (>2.5 ha) (default: the } \\
\text { landless) }\end{array}$ & 51917 & 0.131 & 0.337 & 0 & 1 & 17287 & 0.223 & 0.416 & 0 & 1 \\
\hline $\begin{array}{l}\text { Whether self-employed in } \\
\text { non-agriculture }\end{array}$ & 51917 & 0.119 & 0.324 & 0 & 1 & 17287 & 0.124 & 0.330 & 0 & 1 \\
\hline Whether agricultural labour & 51917 & 0.231 & 0.421 & 0 & 1 & 17287 & 0.277 & 0.448 & 0 & 1 \\
\hline Whether non-agricultural labour & 51917 & 0.064 & 0.245 & 0 & 1 & 17287 & 0.102 & 0.303 & 0 & 1 \\
\hline $\begin{array}{l}\text { Whether a household belongs to } \\
\text { SC (Scheduled Caste) }\end{array}$ & 51917 & 0.139 & 0.346 & 0 & 1 & 17287 & 0.182 & 0.386 & 0 & 1 \\
\hline $\begin{array}{c}\text { Whether a household belongs to } \\
\text { ST (Scheduled Tribe) }\end{array}$ & 51917 & 0.193 & 0.394 & 0 & 1 & 17287 & 0.174 & 0.379 & 0 & 1 \\
\hline PDS & 51917 & 0.000 & 0.000 & 0 & 0 & 17287 & 1.000 & 0.000 & 1 & 1 \\
\hline RPW & 51917 & 0.044 & 0.206 & 0 & 1 & 17287 & 0.054 & 0.226 & 0 & 1 \\
\hline $\begin{array}{l}\text { Predicted agricultural wage rate } \\
\text { for males }\end{array}$ & 51917 & 63.104 & 19.911 & 29.56 & 141.06 & 17287 & 72.332 & 19.312 & 29.55586 & 141.0612 \\
\hline Food Price Index & 51917 & 99.353 & 6.164 & 91.8 & 116.5 & 17287 & 103.290 & 6.219 & 91.8 & 116.5 \\
\hline Poor & 45217 & 0.168 & 0.374 & 0 & 1 & 13446 & 0.312 & 0.463 & 0 & 1 \\
\hline poor (calorie based) & 45217 & 0.175 & 0.380 & 0 & 1 & 13446 & 0.301 & 0.459 & 0 & 1 \\
\hline poor (protein based) & 45217 & 0.128 & 0.334 & 0 & 1 & 13446 & 0.250 & 0.433 & 0 & 1 \\
\hline $\begin{array}{l}\text { Vulnerability Measure (based on } \\
100 \% \text { income poverty line) }\end{array}$ & 45217 & 0.584 & 0.476 & 0 & 1 & 13446 & 0.539 & 0.479 & 0 & 1 \\
\hline $\begin{array}{l}\text { Vulnerability Measure (based on } \\
\quad 80 \% \text { income poverty line) }\end{array}$ & 45217 & 0.447 & 0.478 & 0 & 1 & 13446 & 0.392 & 0.466 & 0 & 1 \\
\hline $\begin{array}{l}\text { Vulnerability Measure (based on } \\
120 \% \text { income poverty line) }\end{array}$ & 45217 & 0.677 & 0.453 & 0 & 1 & 13446 & 0.646 & 0.462 & 0 & 1 \\
\hline
\end{tabular}


NSS 61

\begin{tabular}{|c|c|c|c|c|c|c|c|c|c|c|}
\hline \multicolumn{2}{|l|}{ Without RPW } & \multicolumn{9}{|c|}{ With RPW } \\
\hline Variable & Obs & Mean & Std. Dev. & Min & $\operatorname{Max}$ & Obs & Mean & Std. Dev. & Min & $\operatorname{Max}$ \\
\hline $\begin{array}{c}\text { Whether a household is headed } \\
\text { by a female member }\end{array}$ & 76709 & 0.109 & 0.311 & 0 & 1 & 2290 & 0.072 & 0.259 & 0 & 1 \\
\hline $\begin{array}{l}\text { Number of adult female } \\
\text { members }\end{array}$ & 76709 & 1.337 & 0.807 & 0 & 11 & 2290 & 1.313 & 0.727 & 0 & 6 \\
\hline Number of adult male members & 76709 & 1.344 & 0.939 & 0 & 12 & 2290 & 1.383 & 0.830 & 0 & 6 \\
\hline $\begin{array}{l}\text { The proportion of adults in a } \\
\text { household }\end{array}$ & 76709 & 0.555 & 0.248 & 0 & 1 & 2290 & 0.553 & 0.224 & 0 & 1 \\
\hline Age of household head & 76708 & 0.462 & 0.135 & 0 & 1.08 & 2290 & 0.445 & 0.127 & 0.1 & 0.85 \\
\hline Age squared & 76708 & 0.232 & 0.133 & 0 & 1.1664 & 2290 & 0.215 & 0.122 & 0.01 & 0.7225 \\
\hline $\begin{array}{l}\text { The max. education of adult } \\
\text { (Primary) }\end{array}$ & 76414 & 0.191 & 0.393 & 0 & 1 & 2287 & 0.272 & 0.445 & 0 & 1 \\
\hline $\begin{array}{l}\text { The max. education of adult } \\
\text { (Middle) }\end{array}$ & 76414 & 0.354 & 0.478 & 0 & 1 & 2287 & 0.333 & 0.471 & 0 & 1 \\
\hline $\begin{array}{l}\text { The max. education of adult } \\
\text { (>=Matriculates) }\end{array}$ & 76414 & 0.233 & 0.423 & 0 & 1 & 2287 & 0.079 & 0.270 & 0 & 1 \\
\hline $\begin{array}{c}\text { Land }(0.1<=2.5 \mathrm{ha}) \text { (default: the } \\
\text { landless) }\end{array}$ & 76709 & 0.519 & 0.500 & 0 & 1 & 2290 & 0.597 & 0.491 & 0 & 1 \\
\hline $\begin{array}{l}\text { Land (>2.5 ha) (default: the } \\
\text { landless) }\end{array}$ & 76709 & 0.100 & 0.300 & 0 & 1 & 2290 & 0.069 & 0.254 & 0 & 1 \\
\hline $\begin{array}{l}\text { Whether self-employed in } \\
\text { non-agriculture }\end{array}$ & 76654 & 0.228 & 0.419 & 0 & 1 & 2289 & 0.127 & 0.333 & 0 & 1 \\
\hline Whether agricultural labour & 76654 & 0.144 & 0.351 & 0 & 1 & 2289 & 0.228 & 0.419 & 0 & 1 \\
\hline Whether non-agricultural labour & 76654 & 0.105 & 0.307 & 0 & 1 & 2289 & 0.239 & 0.427 & 0 & 1 \\
\hline $\begin{array}{l}\text { Whether self-employed in } \\
\quad \text { agriculture }\end{array}$ & 76654 & 0.352 & 0.478 & 0 & 1 & 2289 & 0.377 & 0.485 & 0 & 1 \\
\hline $\begin{array}{l}\text { Whether a household belongs to } \\
\text { SC (Scheduled Caste) }\end{array}$ & 76689 & 0.155 & 0.362 & 0 & 1 & 2288 & 0.362 & 0.481 & 0 & 1 \\
\hline $\begin{array}{c}\text { Whether a household belongs to } \\
\text { ST (Scheduled Tribe) }\end{array}$ & 76689 & 0.173 & 0.378 & 0 & 1 & 2288 & 0.201 & 0.401 & 0 & 1 \\
\hline PDS & 76709 & 0.735 & 0.441 & 0 & 1 & 2290 & 0.892 & 0.311 & 0 & 1 \\
\hline RPW & 76709 & 0.000 & 0.000 & 0 & 0 & 2290 & 1.000 & 0.000 & 1 & 1 \\
\hline $\begin{array}{l}\text { Predicted agricultural wage rate } \\
\text { for males }\end{array}$ & 74755 & 60.891 & 18.226 & 35.4 & 123.65 & 2289 & 58.012 & 9.653 & 35.4 & 123.65 \\
\hline Food Price Index & 76709 & 9.691 & 2.014 & 6.66 & 15.691 & 2290 & 9.900 & 2.330 & 6.660041 & 14.85233 \\
\hline Poor & 76708 & 0.176 & 0.381 & 0 & 1 & 2290 & 0.325 & 0.468 & 0 & 1 \\
\hline $\begin{array}{l}\text { Vulnerability Measure (based on } \\
100 \% \text { income poverty line) }\end{array}$ & 76339 & 0.078 & 0.241 & 0 & 1 & 2285 & 0.166 & 0.334 & 0 & 1 \\
\hline $\begin{array}{l}\text { Vulnerability Measure (based on } \\
80 \% \text { income poverty line) }\end{array}$ & 76339 & 0.014 & 0.101 & 0 & 1 & 2285 & 0.047 & 0.190 & 0 & 1 \\
\hline $\begin{array}{l}\text { Vulnerability Measure (based on } \\
120 \% \text { income poverty line) }\end{array}$ & 76339 & 0.203 & 0.370 & 0 & 1 & 2285 & 0.363 & 0.436 & 0 & 1 \\
\hline
\end{tabular}




\begin{tabular}{|c|c|c|c|c|c|c|c|c|c|c|}
\hline Without RPW & & & & & & With RPW & & & & \\
\hline Variable & Obs & Mean & Std. Dev. & Min & Max & Obs & Mean & Std. Dev. & Min & Max \\
\hline $\begin{array}{l}\text { Whether a household is headed by } \\
\text { a female member }\end{array}$ & 20700 & 0.101 & 0.302 & 0 & 1 & 58554 & 0.110 & 0.312 & 0 & 1 \\
\hline Number of adult female members & 20700 & 1.283 & 0.819 & 0 & 8 & 58554 & 1.356 & 0.799 & 0 & 11 \\
\hline Number of adult male members & 20700 & 1.323 & 0.924 & 0 & 10 & 58554 & 1.353 & 0.940 & 0 & 12 \\
\hline $\begin{array}{c}\text { The proportion of adults in a } \\
\text { household }\end{array}$ & 20700 & 0.570 & 0.257 & 0 & 1 & 58554 & 0.550 & 0.243 & 0 & 1 \\
\hline Age of household head & 20700 & 0.447 & 0.139 & 0 & 1 & 58553 & 0.467 & 0.133 & 0 & 1.08 \\
\hline Age squared & 20700 & 0.219 & 0.133 & 0 & 1 & 58553 & 0.235 & 0.133 & 0 & 1.1664 \\
\hline $\begin{array}{l}\text { The max. education of adult } \\
\text { (Primary) }\end{array}$ & 20486 & 0.164 & 0.370 & 0 & 1 & 58469 & 0.204 & 0.403 & 0 & 1 \\
\hline $\begin{array}{l}\text { The max. education of adult } \\
\text { (Middle) }\end{array}$ & 20486 & 0.353 & 0.478 & 0 & 1 & 58469 & 0.353 & 0.478 & 0 & 1 \\
\hline $\begin{array}{l}\text { The max. education of adult } \\
\text { (>=Matriculates) }\end{array}$ & 20486 & 0.291 & 0.454 & 0 & 1 & 58469 & 0.208 & 0.406 & 0 & 1 \\
\hline $\begin{array}{c}\text { Land }(0.1<=2.5 \text { ha) (default: the } \\
\text { landless) }\end{array}$ & 20700 & 0.447 & 0.497 & 0 & 1 & 58554 & 0.547 & 0.498 & 0 & 1 \\
\hline $\begin{array}{c}\text { Land (>2.5 ha) (default: the } \\
\text { landless) }\end{array}$ & 20700 & 0.140 & 0.347 & 0 & 1 & 58554 & 0.086 & 0.280 & 0 & 1 \\
\hline $\begin{array}{l}\text { Whether self-employed in } \\
\text { non-agriculture }\end{array}$ & 20682 & 0.214 & 0.410 & 0 & 1 & 58512 & 0.229 & 0.420 & 0 & 1 \\
\hline Whether agricultural labour & 20682 & 0.111 & 0.314 & 0 & 1 & 58512 & 0.158 & 0.365 & 0 & 1 \\
\hline Whether non-agricultural labour & 20682 & 0.093 & 0.290 & 0 & 1 & 58512 & 0.115 & 0.319 & 0 & 1 \\
\hline $\begin{array}{l}\text { Whether self-employed in } \\
\text { agriculture }\end{array}$ & 20682 & 0.353 & 0.478 & 0 & 1 & 58512 & 0.352 & 0.478 & 0 & 1 \\
\hline $\begin{array}{l}\text { Whether a household belongs to } \\
\text { SC (Scheduled Caste) }\end{array}$ & 20696 & 0.219 & 0.413 & 0 & 1 & 58536 & 0.142 & 0.349 & 0 & 1 \\
\hline $\begin{array}{c}\text { Whether a household belongs to } \\
\text { ST (Scheduled Tribe) }\end{array}$ & 20696 & 0.147 & 0.354 & 0 & 1 & 58536 & 0.182 & 0.386 & 0 & 1 \\
\hline PDS & 20700 & 0.000 & 0.000 & 0 & 0 & 58554 & 1.000 & 0.000 & 1 & 1 \\
\hline RPW & 20576 & 0.012 & 0.109 & 0 & 1 & 58423 & 0.035 & 0.184 & 0 & 1 \\
\hline $\begin{array}{l}\text { Predicted agricultural wage rate for } \\
\text { males }\end{array}$ & 20037 & 62.310 & 17.651 & 35.4 & 123.65 & 57261 & 60.283 & 18.113 & 35.4 & 123.65 \\
\hline Food Price Index & 20700 & 9.586 & 2.098 & 6.66 & 15.691 & 58554 & 9.743 & 1.999 & 6.660041 & 15.69119 \\
\hline Poor & 20699 & 0.126 & 0.332 & 0 & 1 & 58554 & 0.199 & 0.399 & 0 & 1 \\
\hline $\begin{array}{l}\text { Vulnerability Measure (based on } \\
100 \% \text { income poverty line) }\end{array}$ & 20464 & 0.063 & 0.220 & 0 & 1 & 58410 & 0.086 & 0.252 & 0 & 1 \\
\hline $\begin{array}{l}\text { Vulnerability Measure (based on } \\
80 \% \text { income poverty line) }\end{array}$ & 20464 & 0.011 & 0.087 & 0 & 1 & 58410 & 0.017 & 0.110 & 0 & 1 \\
\hline $\begin{array}{l}\text { Vulnerability Measure (based on } \\
120 \% \text { income poverty line) }\end{array}$ & 20464 & 0.155 & 0.335 & 0 & 1 & 58410 & 0.226 & 0.383 & 0 & 1 \\
\hline
\end{tabular}




\begin{tabular}{|c|c|c|c|c|c|c|c|c|c|c|c|c|c|c|}
\hline \multicolumn{15}{|c|}{ Appendix 2 Daily Allowances of Nutrients for Indians (Recommended by the Nutrition Expert Group in 1968) } \\
\hline \multirow[t]{2}{*}{ Group } & \multirow[t]{2}{*}{ Particulars } & \multirow[t]{2}{*}{ Calories } & \multirow{2}{*}{$\begin{array}{l}\text { Proteins } \\
\text { (gm.) }\end{array}$} & \multirow{2}{*}{$\begin{array}{l}\text { Calcium } \\
\text { (gm.) }\end{array}$} & \multirow{2}{*}{$\begin{array}{l}\text { Iron } \\
\text { (mg.) }\end{array}$} & \multicolumn{2}{|c|}{ Vitamin A } & \multirow{2}{*}{$\begin{array}{l}\text { Thiamine } \\
\text { (mg.) }\end{array}$} & \multirow{2}{*}{$\begin{array}{l}\text { Riboflavin } \\
\text { (mg.) }\end{array}$} & \multirow{2}{*}{$\begin{array}{l}\text { Nictonic } \\
\text { acid } \\
\text { (mg.) } \\
\end{array}$} & \multirow{2}{*}{$\begin{array}{c}\text { Ascorbic } \\
\text { acid } \\
\text { (mg.) }\end{array}$} & \multirow{2}{*}{$\begin{array}{l}\text { Folic } \\
\text { Acid } \\
\left(\mu_{g}\right) \\
\end{array}$} & \multirow{2}{*}{$\begin{array}{c}\text { Vitamin } \\
\text { B12 } \\
\left(\mu_{\mathrm{g}}\right) \\
\end{array}$} & \multirow{2}{*}{$\frac{\text { Vitamin D }}{200}$} \\
\hline & & & & & & $\begin{array}{c}\text { Retinol } \\
\left(\mu_{\mathrm{g}}\right)\end{array}$ & $\begin{array}{c}\beta \text {-carotene } \\
\left(\mu_{\mathrm{g}}\right)\end{array}$ & & & & & & & \\
\hline \multirow[t]{3}{*}{ Man } & Sedentary work & 2400 & 55 & 0.4 to 0.5 & 20 & 750 & 3000 & 1.2 & 1.3 & 16 & 50 & 100 & 1 & 200 \\
\hline & Moderate work & 2800 & 55 & 0.4 to 0.5 & 20 & 750 & 3000 & 1.4 & 1.5 & 19 & 50 & 100 & 1 & 200 \\
\hline & Heavy work & 3900 & 55 & 0.4 to 0.5 & 20 & 750 & 3000 & 2.0 & 2.2 & 26 & 50 & 100 & 1 & 200 \\
\hline \multirow[t]{5}{*}{ Woman } & Sedentary work & 1900 & 45 & 0.4 to 0.5 & 30 & 750 & 3000 & 1.0 & 1.0 & 13 & 50 & 100 & 1 & 200 \\
\hline & Moderate work & 2200 & 45 & 0.4 to 0.5 & 30 & 750 & 3000 & 1.1 & 1.2 & 15 & 50 & 100 & 1 & 200 \\
\hline & Heavy work & 3000 & 45 & 0.4 to 0.5 & 30 & 750 & 3000 & 1.5 & 1.7 & 20 & 50 & 100 & 1 & 200 \\
\hline & Second Half of pregnancy & +300 & +10 & 1.0 & 40 & 750 & 3000 & +0.2 & +0.2 & +2 & 50 & $150-300$ & 1.5 & 200 \\
\hline & Lactation Up to one year & +700 & +20 & 1.0 & 30 & 1150 & 4600 & +0.4 & +0.4 & +5 & 80 & 150 & 1.5 & 200 \\
\hline \multirow[t]{2}{*}{ Infants } & $0-6$ months & $120 / \mathrm{kg}$ & $2.3-1.8 / \mathrm{kg}$ & & $1 \mathrm{mg} / \mathrm{kg}$ & 400 & & & & 30 & & & & 200 \\
\hline & $7-12$ months & $100 / \mathrm{kg}$ & $1.8-1.5 / \mathrm{kg}$ & $0.5-0.6$ & & 300 & 1200 & & & 30 & 25 & 0.2 & & 200 \\
\hline \multirow[t]{6}{*}{ Children } & 1 year & 1200 & 17 & $0.4-0.5$ & $15-20$ & 250 & 1000 & 0.6 & 0.7 & 8 & $30-50$ & $50-100$ & $0.5-1$ & 200 \\
\hline & 2 years & 1200 & 18 & $0.4-0.5$ & $15-20$ & 250 & 1000 & 0.6 & 0.7 & 8 & $30-50$ & $50-100$ & $0.5-1$ & 200 \\
\hline & 3 years & 1200 & 20 & $0.4-0.5$ & $15-20$ & 250 & 1000 & 0.6 & 0.7 & 8 & $30-50$ & $50-100$ & $0.5-1$ & 200 \\
\hline & $4-6$ years & 1500 & 22 & $04-0.5$ & & 300 & 1200 & 0.8 & 0.8 & 10 & $30-50$ & $50-100$ & $0.5-1$ & 200 \\
\hline & $7-9$ years & 1800 & 33 & $04-0.5$ & & 400 & 1600 & 0.9 & 1.0 & 12 & $30-50$ & $50-100$ & $0.5-1$ & 200 \\
\hline & $10-12$ years & 2100 & 41 & $04-0.5$ & & 600 & 2400 & 1.0 & 1.2 & 14 & $30-50$ & $50-100$ & $0.5-1$ & 200 \\
\hline \multirow[t]{4}{*}{ Adolescents } & $13-15$ years boys & 2500 & 55 & $0.6-0.7$ & 25 & 750 & 3000 & 1.3 & 1.4 & 17 & $30-50$ & $50-100$ & $0.5-1$ & 200 \\
\hline & $13-15$ years girls & 2200 & 50 & $0.6-0.7$ & 35 & 750 & 3000 & 1.1 & 1.2 & 14 & $30-50$ & $50-100$ & $0.5-1$ & 200 \\
\hline & $16-18$ years boys & 3000 & 60 & $0.5-0.6$ & 25 & 750 & 3000 & 1.5 & 1.7 & 21 & $30-50$ & $50-100$ & $0.5-1$ & 200 \\
\hline & 16-18 years girls & 2200 & 50 & $0.5-0.6$ & 35 & 750 & 3000 & 1.1 & 1.2 & 14 & $30-50$ & $50-100$ & $0.5-1$ & 200 \\
\hline
\end{tabular}

Source Gopalan et. al. (1971), p. 27. 


\begin{tabular}{|c|c|c|c|c|}
\hline \multicolumn{5}{|c|}{$\begin{array}{l}\text { Appendix } 3 \\
\text { Wage Equations for male and female workers in rural areas based on NSS data in } 1993 \text { and } 2004\end{array}$} \\
\hline & \multicolumn{2}{|c|}{1993} & \multicolumn{2}{|c|}{2004} \\
\hline & Male wage & Female Wage & $\begin{array}{l}\text { Male } \\
\text { Wage }\end{array}$ & Female Wage \\
\hline & Coef. & Coef. & Coef. & Coef. \\
\hline & (t value) & (t value) & (t value) & (t value) \\
\hline \multirow[t]{2}{*}{ Land Owned } & 0.349 & -0.324 & 0.00 & -0.082 \\
\hline & $(0.98)$ & $(4.86)^{\star *}$ & $(2.39)^{*}$ & $(8.35)^{* *}$ \\
\hline \multirow[t]{2}{*}{ Scheduled Tribe (ST) dummy (ST=1, otherwise $=0$ ) } & -322.569 & $-1,018.14$ & -121.41 & -108.96 \\
\hline & $(0.87)$ & $(4.08)^{\star *}$ & $(9.13)^{\star *}$ & $(7.53)^{* *}$ \\
\hline \multirow[t]{2}{*}{ Scheduled Caste (SC) dummy (SC=1, otherwise $=0$ ) } & $-2,177.57$ & -381.166 & - & - \\
\hline & $(7.95)^{* *}$ & (1.89) & & \\
\hline \multirow[t]{2}{*}{$\begin{array}{l}\text { non-agricultural self employment dummy } \\
\text { (non-agricultural self employment=1 otherwise) }\end{array}$} & $7,216.57$ & $2,324.92$ & $1,859.26$ & 566.23 \\
\hline & $(10.27)^{\star *}$ & $(5.49)^{\star *}$ & $(68.44)^{* \star}$ & $(21.97)^{* *}$ \\
\hline \multirow{2}{*}{$\begin{array}{c}\text { agricultural self employment dummy } \\
\text { (agricultural self employment=1 otherwise=0) }\end{array}$} & $7,899.48$ & $5,204.41$ & $2,196.08$ & 880.79 \\
\hline & $(15.13)^{\star *}$ & $(14.37)^{* \star}$ & $(69.07)^{\star *}$ & $(22.83)^{* *}$ \\
\hline \multirow[t]{2}{*}{ Muslim dummy(Muslim=1, otherwise=0) } & 746.744 & 185.894 & 113.494 & -330.9 \\
\hline & $(1.61)$ & $(0.46)$ & $(5.59)^{\star \star}$ & $(10.79)^{* *}$ \\
\hline \multirow[t]{2}{*}{ Age } & 662.822 & 204.695 & 139.625 & 49.933 \\
\hline & $(8.65)^{\star \star}$ & $(3.65)^{\star *}$ & $(37.08)^{* \star}$ & $(10.15)^{* *}$ \\
\hline \multirow[t]{2}{*}{$\mathrm{Age}^{2}$} & -4.072 & -1.257 & -1.638 & -0.637 \\
\hline & $(4.17)^{* *}$ & $(1.69)$ & $(39.07)^{\star \star}$ & $(10.24)^{* *}$ \\
\hline \multirow[t]{2}{*}{ Whether is literate, but has not completed primary school } & $3,542.99$ & $2,126.39$ & 92.081 & -205.98 \\
\hline & $(12.71)^{\star \star}$ & $(7.36)^{\star *}$ & $(5.10)^{\star *}$ & $(8.72)^{\star \star}$ \\
\hline \multirow[t]{2}{*}{ Whether mother completed primary school } & $7,518.66$ & $3,208.70$ & 175.043 & -227.04 \\
\hline & $(23.01)^{* *}$ & $(7.49)^{* *}$ & $(9.45)^{* *}$ & $(9.53)^{\star \star}$ \\
\hline \multirow[t]{2}{*}{ Whether mother completed middle school } & $14,163.75$ & $10,200.92$ & 360.514 & -192.21 \\
\hline & $(29.57)^{\star \star}$ & $(8.09)^{\star *}$ & $(19.49)^{* *}$ & $(7.37)^{\star *}$ \\
\hline \multirow[t]{2}{*}{ Whether completed secondary or higher secondary school } & $35,055.00$ & $38,201.86$ & 810.913 & 201.04 \\
\hline & $(56.87)^{\star \star}$ & $(26.88)^{* *}$ & $(33.86)^{* *}$ & $(5.63)^{\star *}$ \\
\hline \multirow[t]{2}{*}{ Whether completed higher education } & $57,151.06$ & $53,253.26$ & $1,473.09$ & $1,004.51$ \\
\hline & $(47.65)^{\star *}$ & $(17.32)^{\star \star}$ & $(64.15)^{* *}$ & $(20.43)^{* *}$ \\
\hline \multirow[t]{2}{*}{ Constant } & $-2,171.00$ & $4,216.78$ & $-2,940.20$ & $-1,749.97$ \\
\hline & $(1.50)$ & $(4.18)^{\star *}$ & $(34.97)^{\star \star}$ & $(16.65)^{\star *}$ \\
\hline Observations & 33720 & 15849 & 67168 & 59221 \\
\hline
\end{tabular}

Robust z-statistics in parentheses

${ }^{*}$ significant at $5 \%$ level; ** significant at $1 \%$ level 


\section{Appendix 4 Distributions of Propensity Scores}

\begin{tabular}{|c|c|c|c|c|c|c|c|c|c|c|}
\hline \multirow[t]{5}{*}{ Case 1} & \multirow{2}{*}{$\begin{array}{l}\text { NSS 50, RPW } \\
\text { RPW }\end{array}$} & \multirow[b]{2}{*}{ Freq. } & \multirow[b]{2}{*}{ Percent } & \multirow[b]{2}{*}{ Cum. } & \multirow[t]{2}{*}{ Case 1} & \multicolumn{2}{|r|}{ Percentiles } & Smallest & & \\
\hline & & & & & & $1 \%$ & 0.9343881 & 0.695964 & & \\
\hline & 0 & 65,974 & 95.33 & 100 & & $5 \%$ & 0.9420734 & 0.7824953 & & \\
\hline & 1 & 3,232 & 4.67 & 4.67 & & $10 \%$ & 0.9452703 & 0.8199315 & Obs & 69206 \\
\hline & Total & 69,206 & 100 & & & $25 \%$ & 0.9496597 & 0.8401137 & Sum of Wgt. & 69206 \\
\hline & & & & & & $50 \%$ & 0.9537689 & & Mean & 0.9532995 \\
\hline & & & & & & & & Largest & Std. Dev. & 0.0067562 \\
\hline & & & & & & $75 \%$ & 0.957319 & 0.9978209 & & \\
\hline & & & & & & $90 \%$ & 0.9608813 & 0.9984333 & Variance & 0.0000456 \\
\hline & & & & & & $95 \%$ & 0.9633145 & 0.9997452 & Skewness & -1.717206 \\
\hline & & & & & & $99 \%$ & 0.9677861 & 0.9998932 & Kurtosis & 45.64713 \\
\hline \multirow[t]{12}{*}{ Case 2} & NSS 50, RPW & & & & Case 2 & & & & & \\
\hline & PDS & & & & & & Percentiles & Smallest & & \\
\hline & 0 & 51,917 & 75.02 & 75.02 & & $1 \%$ & 0.0688306 & $9.02 \mathrm{E}-09$ & & \\
\hline & 1 & 17,287 & 24.98 & 100 & & $5 \%$ & 0.1033367 & $7.27 \mathrm{E}-08$ & & \\
\hline & Total & 69,204 & 100 & & & $10 \%$ & 0.1135362 & $1.51 \mathrm{E}-06$ & Obs & 69194 \\
\hline & & & & & & $25 \%$ & 0.1487656 & $3.36 \mathrm{E}-06$ & Sum of Wgt. & 69194 \\
\hline & & & & & & $50 \%$ & 0.2280811 & & Mean & 0.2494196 \\
\hline & & & & & & & & Largest & Std. Dev. & 0.1237115 \\
\hline & & & & & & $75 \%$ & 0.3274996 & 0.666051 & & \\
\hline & & & & & & $90 \%$ & 0.4201916 & 0.6677483 & Variance & 0.0153045 \\
\hline & & & & & & $95 \%$ & 0.5159592 & 0.6677483 & Skewness & 0.8970378 \\
\hline & & & & & & $99 \%$ & 0.5957185 & 0.6694421 & Kurtosis & 3.352018 \\
\hline
\end{tabular}


Case NSS 61, RPW

\begin{tabular}{ccccc} 
FFW & work & Freq. & Percent & Cum. \\
\hline & 0 & 76,709 & 97.1 & 97.1 \\
& 1 & 2,290 & 2.9 & 100 \\
& Total & 78,999 & 100 &
\end{tabular}

Case NSS 61, PDS
4

\begin{tabular}{ccccc} 
PDS & & Freq. & Percent & Cum. \\
\hline & 0 & 58,554 & 73.88 & 100 \\
& 1 & 20,700 & 26.12 & 26.12 \\
& Total & 79,254 & 100 &
\end{tabular}

Case 3

\begin{tabular}{ccccc} 
& Percentiles & Smallest & & \\
\hline $1 \%$ & 0.0127803 & 0.0110351 & & \\
$5 \%$ & 0.0183658 & 0.0110357 & & \\
$10 \%$ & 0.0218692 & 0.011036 & Obs & 76935 \\
$25 \%$ & 0.0261054 & 0.0110371 & Sum of Wgt. & 76935 \\
& & & & \\
$50 \%$ & 0.03031 & & Mean & 0.0297765 \\
& & Largest & Std. Dev. & 0.0061051 \\
$75 \%$ & 0.0341994 & 0.0475447 & & \\
$90 \%$ & 0.0370002 & 0.0475723 & Variance & 0.0000373 \\
$95 \%$ & 0.0384776 & 0.0475776 & Skewness & -0.5237902 \\
$99 \%$ & 0.041977 & 0.0476086 & Kurtosis & 3.257123
\end{tabular}

Case 4

\begin{tabular}{|c|c|c|c|c|}
\hline & Percentiles & Smallest & & \\
\hline $1 \%$ & 0.6507831 & 0.3185633 & & \\
\hline $5 \%$ & 0.6816596 & 0.6100912 & & \\
\hline $10 \%$ & 0.6959432 & 0.6124564 & Obs & 79253 \\
\hline $25 \%$ & 0.7159724 & 0.6126622 & Sum of Wgt. & 79253 \\
\hline
\end{tabular}

$\begin{array}{ccccc}50 \% & 0.7373254 & & \text { Mean } & 0.7387706 \\ & & \text { Largest } & \text { Std. Dev. } & 0.0355197 \\ 75 \% & 0.7613883 & 0.8623071 & & \\ 90 \% & 0.7859754 & 0.8624616 & \text { Variance } & 0.0012617 \\ 95 \% & 0.799535 & 0.8629799 & \text { Skewness } & 0.0085923 \\ 99 \% & 0.8221764 & 0.8725297 & \text { Kurtosis } & 3.381942\end{array}$

